\title{
Environmental pollutants, a possible etiology for premature ovarian insufficiency: a narrative review of animal and human data
}

Pauline Vabre ${ }^{1}$, Nicolas Gatimel ${ }^{1,2}$, Jessika Moreau', Véronique Gayrard ${ }^{3,4}$, Nicole Picard-Hagen ${ }^{3,4}$, Jean Parinaud ${ }^{1,2^{*}}$ (D) and Roger D. Leandri, ${ }^{1,2}$

\begin{abstract}
Background: Because only 25\% of cases of premature ovarian insufficiency (POI) have a known etiology, the aim of this review was to summarize the associations and mechanisms of the impact of the environment on this pathology.

Main body of the abstract: Eligible studies were selected from an electronic literature search from the PUBMED database from January 2000 to February 2016 and associated references in published studies. Search terms included ovary, follicle, oocyte, endocrine disruptor, environmental exposure, occupational exposure, environmental contaminant, pesticide, polyaromatic hydrocarbon, polychlorinated biphenyl PCB, phenol, bisphenol, flame retardant, phthalate, dioxin, phytoestrogen, tobacco, smoke, cigarette, cosmetic, xenobiotic. The literature search was conducted in accordance with the Preferred Reporting Items for Systematic Reviews and Meta-Analyses (PRISMA) guidelines. We have included the human and animal studies corresponding to the terms and published in English. We have excluded articles that included results that did not concern ovarian pathology and those focused on ovarian cancer, polycystic ovary syndrome, endometriosis or precocious puberty. We have also excluded genetic, auto-immune or iatrogenic causes from our analysis. Finally, we have excluded animal data that does not concern mammals and studies based on results from in vitro culture. Data have been grouped according to the studied pollutants in order to synthetize their impact on follicular development and follicular atresia and the molecular pathways involved.

Ninety-seven studies appeared to be eligible and were included in the present study, even though few directly address POI. Phthalates, bisphenol A, pesticides and tobacco were the most reported substances having a negative impact on ovarian function with an increased follicular depletion leading to an earlier age of menopause onset. These effects were found when exposure occured at different times throughout the lifetime from the prenatal to the adult period, possibly due to different mechanisms. The main mechanism seemed to be an increase in atresia of pre-antral follicles.
\end{abstract}

Conclusion: Environmental pollutants are probably a cause of POI. Health officials and the general public must be aware of this environmental effect in order to implement individual and global preventive actions.

Keywords: Premature ovarian insufficiency, Ovarian reserve, Environment, Pollutants, Fertility

\footnotetext{
* Correspondence: parinaud.j@chu-toulouse.fr

'Médecine de la Reproduction, CHU de Toulouse, Hôpital Paule de Viguier,

330 avenue de Grande Bretagne, F-31059 Toulouse Cedex, France

${ }^{2}$ Université de Toulouse; UPS; Groupe de Recherche en Fertilité Humaine (EA

3694, Human Fertility Research Group), F-31059 Toulouse, France

Full list of author information is available at the end of the article
} 


\section{Background}

Over the last few decades, much evidence has been gathered that confirms that certain chemical, physical and biological substances present in our environment produce harmful effects on human reproduction [1].

Environmental pollutants refer to all of the exogenic, non-essential factors for humans, which, when released into the environment, can be detrimental to human health and/or to the environment. The industrialization of our society maximizes the use of these substances and poses a real problem for public health [2-6].

Premature ovarian insufficiency (POI) is a medical and biological diagnosis that affects young women, altering their quality of life and their fertility. According to the European Society of Human Reproduction and Embryology (ESHRE) guidelines [7], POI is defined by oligo/ amenorrhea for at least 4 months and an elevated FSH level $>25$ IU/l on two occasions $>4$ weeks apart. Its prevalence is about $1 \%$ in women before the age of 40 [7]. Despite this precise definition, this medical diagnosis is very often confused with two other diagnoses that share many pathophysiological substrates: premature menopause (before age 45) for which POI is a major risk factor, and diminished ovarian reserve, which can be a one of the warning signs of POI [8]. The ESHRE Guideline Group on POI defines ovarian reserve [7] as "encompassing both the quantity and quality of primordial follicles".

Etiologies of POI are still poorly defined because in more than $75 \%$ of cases, the cause is undetermined $[9,10]$. Genetic [11], iatrogenic [12], immunologic [13], metabolic [14] and infectious [15, 16] causes have been reported (Table 1). Four main mechanisms can lead to POI (Fig. 1): i) exhaustion of the pool of

Table 1 Main etiologies of premature ovarian insufficiency

\begin{tabular}{|c|c|}
\hline Etiologies & Characteristics \\
\hline $\begin{array}{l}\text { Genetics: [11] } \\
\text { - Chromosomal abnormality } \\
\text { - Genetic mutations }\end{array}$ & $\begin{array}{l}\text { - Monosomy X and mosaicism: Turner } \\
\text { syndrome, triploid syndrome, partial } \\
\text { deletion and X } \\
\text { translocation } \\
\text { - X chromosomes: FMR1 premutation: } \\
\text { Fragile X syndrome } \\
\text { - Other chromosomes: FOX L2 } \\
\text { (blepharophimosis, ptosis), FSHR, } \\
\text { NOBOX, GALT, SF1, GDF1, etc. }\end{array}$ \\
\hline latrogenic: [12] & $\begin{array}{l}\text { - Pelvic, ovarian surgery } \\
\text { - Chemotherapy: alkylating agents ++, } \\
\text { etc. } \\
\text { - Radiotherapy }\end{array}$ \\
\hline Autoimmune disease: [13] & $\begin{array}{l}\text { - Isolated } \\
\text { - Associated: hypothyroidism, type } 1 \\
\text { diabetes, Addison's disease, } \\
\text { myasthenia, lupus, etc. }\end{array}$ \\
\hline Metabolic: [14] & $\begin{array}{l}\text { - Congenital galactosemia } \\
\text { - 17-hydroxylase deficiency }\end{array}$ \\
\hline Infectious: $[15,16]$ & $\begin{array}{l}\text { - HIV infection } \\
\text { - Mumps }\end{array}$ \\
\hline
\end{tabular}

resting primordial follicles (either constitutive due to default in their assembly, or acquired because of their increased atresia), ii) increased follicular atresia, iii) an increased activation of primordial follicles and iv) a blockage of folliculogenesis before the antral stages preventing ovulation.

Environmental factors seem to be major determinants in the ovarian reserve or in premature menopause acting during the prenatal period or during the adult life [17]. Because of this, they are suspected of contributing to the onset of POI. Although the possible environmental impact on POI is often alluded to, the evidence for this relationship has yet not been evaluated.

Environmental pollutants can impact ovarian function in three ways that can coexist:

\section{- Endocrine disrupting chemicals (EDCs): EDCs} have been defined by the Endocine Society as "an exogenous chemical, or mixture of chemicals, that interferes with any aspect of hormone action". Depending on the time of exposure regarding ovarian ontogenesis, EDCs' effects on ovarian functions can be transitory or permanent. They can influence ovarian reserve by acting mainly on the aryl hydrocarbon receptor (AhR) or estrogen receptors (ERs). After binding to its exogenous ligand, AhR translocates toward the nucleus, it associates with a nuclear receptor and is able to bind to DNA sequences and modulates them. AhR induces a Bax synthesis, which is a pro-apoptotic factor contributing to follicular atresia [18]. ERs play evident roles during the gonadotrophins dependant phase of folliculogenesis. However arguments for their role from the very early phases of folliculogenesis are given by the fact that they are increasingly expressed from the primordial stage onward in adult human follicles [19] and consistently expressed by oocytes in human fetal ovaries whatever the follicular stage [20]. In different mammals, estrogens are known to interfere with primordial follicles formation: in a positive manner in primates and bovines, in a negative manner in mice [20].

- Induction of oxidative stress: This occurs when cell mechanisms regulating the level of reactive oxygen species (ROS) are overwhelmed and responsible for an imbalance of ROS. The accumulation of ROS can harm ovarian function. There is solid proof that ROS, induced by environmental factors, are involved in the initiation of antral follicle apoptosis [21]. It was also highlighted that the anti-oxidant capacities differed depending on the follicle stage. A cross-sectional study confirmed the role of oxidative stress in POI 


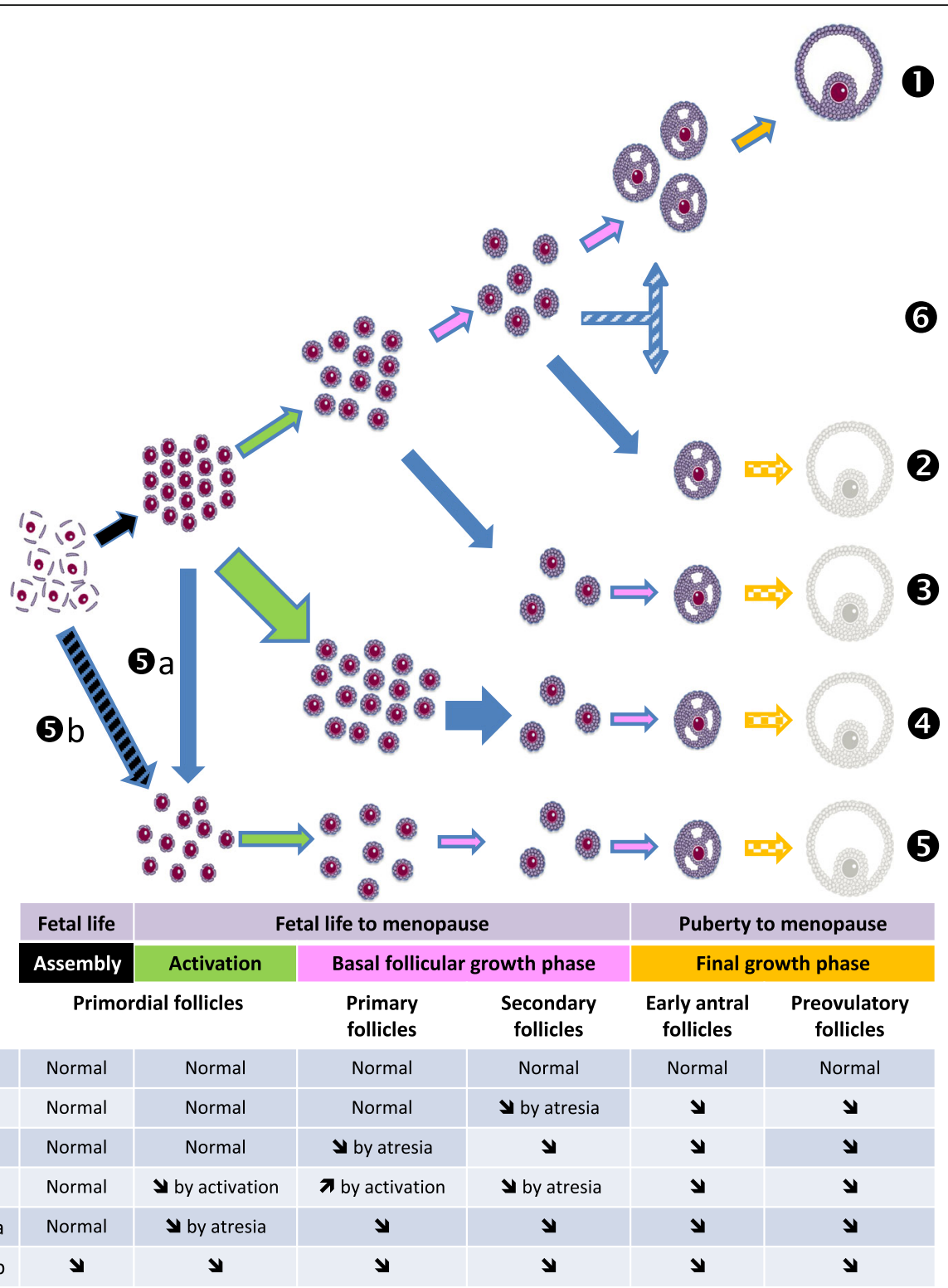

Fig. 1 The different mechanisms inducing POI. Folliculogenesis (0) begins after assembly (black arrows) of primordial follicles during second trimester of pregnancy. Activation of primordial follicles (green color) to enter the growth phase of folliculogenesis is continuous from third trimester of fetal life to menopause. This activation is driven by local factors and is independent of gonadotropins. Basal follicular growth (pink color) is driven by paracrine factors. From the early antral follicle stage, their growth depends on gonadotrophins to enter the final phase (orange color) up to ovulation. From the beginning, follicles undergo physiological atresia (blue lines around arrows), that participate to the decrease of the pool with years. Mechanisms leading to POI (symbolized by a final pale preovulatory follicle,): • decrease of the pool of primordial follicles (5) either due to massive atresia (5a) or default in assembly (0). • increase in follicular apoptosis concerning any other follicular stage (2 and $\mathbf{3})$. • increase of the activation (large green arrow) of the resting pool of primordial follicles (4) resulting in its exhaustion. It is generally followed by increased atresia at following follicular stages (large blue arrow). default in basal follicular growth leading to its arrest before the antral stages preventing ovulation while the pool of primordial follicles is normal $(6)$

pathogenesis by showing that the oxidative stress markers were increased in patients with POI compared to a control group [22].

- Epigenetic modifications: Exposure to environmental pollutants led to modifications in DNA methylation altering ovarian function and, if these modifications affect the germline in a stable way, it will promote transgenerational inheritance of altered ovarian function [23-25].

We wanted to study the role that the environmental contaminants play in the occurrence of POI by 
conducting a systematic review of the scientific literature, which includes human and animal data.

\section{Methods}

\section{Research strategy}

We have conducted a review of the literature concerning the exposure to environmental pollutants and POI. Regarding the articles selected from the literature, our selection was made in compliance with the PRISMA (Preferred Reporting Items for Systematic Reviews and Meta-Analyses) criteria [26].

We conducted the research in February 2016 using the PubMed database. All of the research was done using the Advanced Search Builder and the key words were searched in [Title OR Abstract]. We limited the search to the period from 01/01/2000 to $02 / 26 / 2016$ and to articles written in English.

Our search strategy is summarized in Table 2. Regarding the ovary, we used comprehensive terms in order to optimize the search. Regarding the environment, we opted for a two prong strategy that, in the first stage, combined comprehensive terms and in the second stage, specified by the pollutant names so as not to omit any articles.

In all, we have combined the results from search 1 with those from search 2 according to the following algorithm: Search 1 OR Search 2.

\section{Article inclusion and exclusion criteria}

We have included all of the human and animal studies and reviews responding to the subjects of our search.

We have excluded articles that included results that did not concern ovarian pathology, those focusing on ovarian cancer, polycystic ovary syndrome, endometriosis or precocious puberty. We have also excluded

Table 2 Search strategy: list of keywords used

\begin{tabular}{|c|c|c|}
\hline \multicolumn{3}{|l|}{ Search 1} \\
\hline $\begin{array}{l}\text { Ovary OR } \\
\text { Ovaries OR } \\
\text { Ovarian OR } \\
\text { Oocyte* OR } \\
\text { Ovocyte* OR } \\
\text { Follicle* OR } \\
\text { Follicular }\end{array}$ & AND & $\begin{array}{l}\text { Endocrine disruptor* OR } \\
\text { Environmental exposure* OR } \\
\text { Occupational exposure* OR } \\
\text { Environmental contaminant }\end{array}$ \\
\hline Search 2 & & \\
\hline $\begin{array}{l}\text { Ovary OR } \\
\text { Ovaries OR } \\
\text { Ovarian OR } \\
\text { Oocyte* OR } \\
\text { Ovocyte* OR } \\
\text { Follicle* OR } \\
\text { Follicular }\end{array}$ & AND & $\begin{array}{l}\text { Pesticide* OR } \\
\text { Polyaromatic hydrocarbon* OR } \\
\text { Polychlorinated biphenyl* OR PCB* OR } \\
\text { Phenol*OR Bisphenol* OR } \\
\text { Flame retardant* OR } \\
\text { Phthalate* OR } \\
\text { Dioxin* OR } \\
\text { Phytoestrogen* OR } \\
\text { Tobacco OR smoke* OR cigarette* OR } \\
\text { Cosmetic* OR } \\
\text { Xenobiotic }\end{array}$ \\
\hline
\end{tabular}

genetic, auto-immune or iatrogenic causes from our analysis. Finally, we have excluded animal data that does not concern mammals and studies based on results from in vitro culture.

\section{Results}

We selected 97 citations for analysis following the flowchart presented in Fig. 2.

A cross-sectional study was conducted from 1999 to 2008 on 31,575 women, using NHANES (National Health and Nutrition Examination Survey) data. The aim was to determine the association between exposure to endocrine disruptors and age at menopause. Out of 111 analyzed EDCs, 9 polychlorinated biphenyls (PCBs), 3 pesticides, 1 furan and 2 phthalates were significantly associated with an earlier age of menopause from 1.9 to 3.8 years after adjustment for age, race/ethnicity, smoking, body mass index. A dose-response relationship was demonstrated for 14 of them, suggesting to the authors that the increase in the level of exposure to these long half-life chemicals (except phthalates) could affect ovarian function [27]. However, one has to keep in mind that nonlinear dose-responses of EDCs cannot be ignored despite some continued controversy on this point.

Finally, a review of the literature [28] focused on occupational exposure to chemicals. In total, 1074 articles were selected and 140 chemical substances were analyzed. Twenty agents were retained as likely to induce POI. Eighteen of them, acting via an increase in follicular atresia, including 3 metals (cadmium, lead and chromium), 12 synthetic organic compounds ( 4 pesticides, 3 solvents, 5 compounds used in industrial chemistry) and 3 belonging to the polycyclic aromatic hydrocarbons (PAHs) family.

Two synthetic organic compounds (methoxychlor and bisphenol A) acted by increasing follicular recruitment.

For 15 additional substances, data was insufficient to draw a direct link; however, these substances seem to lead to a decrease in follicle stocks [28].

Phthalates are substances that are currently used in the manufacture of plastics for a very wide spectrum of industrial applications. Two types of phthalates can be distinguished. High molecular weight phthalates (for example, di(2-ethylhexyl) phthalate [DEHP],di-isononyl phthalate [DiNP]), are used as plasticizers in the manufacture of flexible vinyl (such as polyvinyl chloride) used in consumer products (clothing, children's toys, and household items), flooring and wall coverings, food contact applications and medical devices. They are produced in high volume because they give materials a certain flexibility and suppleness. Low molecular weight phthalates (for example, diethyl phthalate [DEP] and dibutyl phthalate $[\mathrm{DBP}]$ ) are used in personal-care products (cosmetics), as solvents and plasticizers for cellulose acetate and in making lacquers, varnishes and coatings 


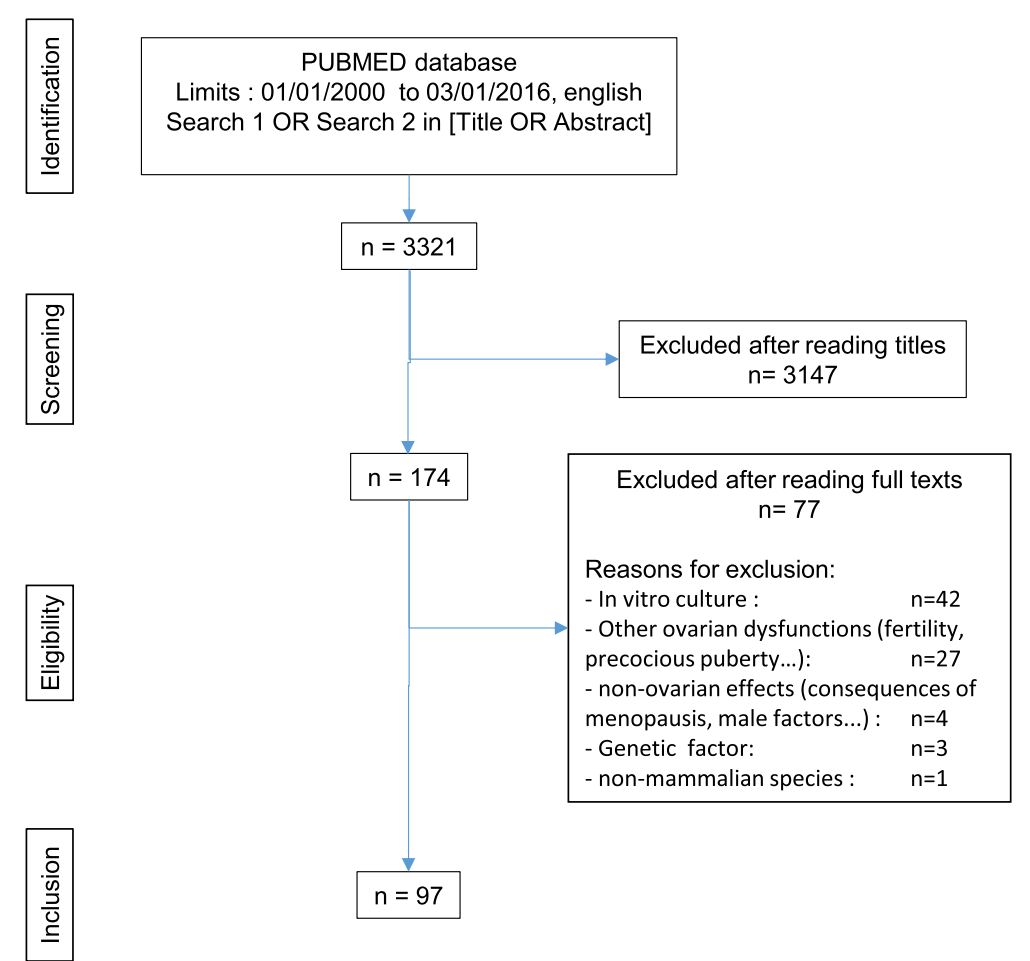

Fig. 2 Flow chart of the selection of articles

including the enteric coating of tablets or capsules and for controlled release formulations.

The most common one is di(2-ethylhexyl)phthalate (DEHP), and its active metabolite mono(2-ethylhexyl)phthalate (MEHP).

Human exposure to DEPH is pervasive and ubiquitous through oral ingestion, inhalation or cutaneous contact. It is estimated between 3 and $30 \mu \mathrm{g} / \mathrm{kg} /$ day (for review see [29]).

Phthalates are described in many studies as being endocrine disruptors altering ovarian function. The toxic effect of phthalates on the ovary rests on folliculogenesis and steroidogenesis disorders with, as a consequence, an alteration in reproductive functions, infertility and POI (for review see [30]). These substances are stable and remain in the environment for several years [29].

The literature review on phthalates and POI has allowed the study of 12 articles and 3 reviews. The study methods and primary results are described in Table 3.

The collected animal data highlight different windows of susceptibility with different effects on folliculogenesis.

When considering foetal development, exposure to MEHP on pregnant mice leads to premature ovarian senescence in the F1 generation [31]. It led to a depletion of the primordial-follicle pool in the F1 and F2 generations, according to an acceleration mechanism in follicular recruitment. The authors concluded to an ovarian toxicity of phthalate with a transgenerational effect [32]. However, because they showed depletion in the primordial-follicle pool in the F1 and F2 generations, populations directly exposed to phthalates via the embryo (F1) or germ cells that it contained (F2), the effect was, more accurately, multigenerational. The effect would have been transgenerational if the F3 generation, which was the first one considered to be unexposed, had been studied and affected. This multigenerational effect is explained by the effect of phthalates on DNA methylation of imprinted genes, not only in fetal ovarian germ cells but also in the F1 and F2 offspring [33]. One study showed an increase in the number of preantral follicles in the offspring at the 21st day of life. The authors explained this increase by an acceleration in the growth of primordial and primary follicles [34].

Regarding the neonatal period, exposure of newborn mice to phthalates significantly decreased the number of primordial follicles at puberty and at the adult age by accelerating follicular recruitment [35].

When exposure to DEHP takes place during the prepubertal period it led to a significant reduction in the percentage of antral follicles with an increase in messenger RNA quantities of pro-apoptotic genes. DEHP causes oxidative stress and ovarian somatic cell apoptosis [36].

Finally, exposing mice during adulthood led to a significant decrease in the number of primordial [37] or antral [38] follicles according to a cell mechanism of apoptosis since there is a significant increase in 
Table 3 Effects of phthalates on ovarian function

\begin{tabular}{|c|c|c|}
\hline References & Methods & Results \\
\hline \multicolumn{3}{|l|}{ Animal Data } \\
\hline Xu et al., 2010 [41] & $\begin{array}{l}\text { Female rats intragastrically exposed to benzo[a]pyrene } \\
\text { (B[a]P) } 5 \text { and } 10 \mathrm{mg} / \mathrm{kg} \text {, to DEHP } 300 \text { and } 600 \mathrm{mg} / \mathrm{kg} \\
\text { and B[a]P + DEHP for } 60 \text { days. }\end{array}$ & $\begin{array}{l}\searrow \text { number of primordial follicles (BaP } 10 \mathrm{mg} / \mathrm{kg} \pm \text { DEHP } \\
600 \mathrm{mg} / \mathrm{kg} \text { ) and of primary/secondary follicles (DEHP } \\
600 \mathrm{mg} / \mathrm{kg} \pm \mathrm{BaP} 10 \mathrm{mg} / \mathrm{kg} \text { ) with granulosa cell apoptosis } \\
\text { increased in DEHP, B[a]P and B[a]P + DEHP groups, implying } \\
\text { a PPAR-mediated signaling pathway for both. No interactior } \\
\text { effect was observed. }\end{array}$ \\
\hline Moyer and Hixon, 2012 [31] & $\begin{array}{l}\text { Pregnant mice exposed by oral gavage to placebo or } \\
100,500 \text { or } 1000 \mathrm{mg} / \mathrm{kg} \text { of MEHP during gestational } \\
\text { days } 17-19 .\end{array}$ & $\begin{array}{l}\searrow \text { by } 1 \text { month of reproductive lifespan in the highest F1 } \\
\text { exposure group ( } 9.8 \pm 0.4 \text { compared to } 11.1 \pm 0.6 \text { months } \\
\text { in the control F1 females) }\end{array}$ \\
\hline Li et al., 2012 [39] & $\begin{array}{l}60 \text { randomized adult mice in } 4 \text { groups exposed to } 0 \text {, } \\
125,500 \text { or } 2000 \mathrm{mg} / \mathrm{kg} \text { of DEHP by gavage for } 16 \\
\text { weeks, } 6 \text { days/week }\end{array}$ & $\begin{array}{l}\text { DEHP arrested granulosa cells in the G0/G1 phases of the } \\
\text { cell cycle and } \gg \text { apoptosis in granulosa cells at } 500 \text { and } \\
2000 \mathrm{mg} / \mathrm{kg}\end{array}$ \\
\hline Zhang et al., 2013 [35] & $\begin{array}{l}\text { Subcutaneous injections of DEHP of } 20 \text { and } 40 \mu \mathrm{g} / \mathrm{kg} \\
\text { in newborn mice }\end{array}$ & $\begin{array}{l}\searrow \text { number of primordial follicles at puberty and adult age } \\
\text { by accelerating follicular recruitment } \\
\searrow \text { DNA methylation of maternal imprinted genes (lgf2r, } \\
\text { Peg3) in oocytes }\end{array}$ \\
\hline Hannon et al., 2014 [40] & $\begin{array}{l}\text { Oral exposure of adult mice to DEHP ( } 20 \mu \mathrm{gg} \text { at } \\
750 \mathrm{mg} / \mathrm{kg} / \text { day) every day for } 10 \text { or } 30 \text { days. }\end{array}$ & $\begin{array}{l}\searrow \text { in the number of primordial follicles and } \gg \text { in the } \\
\text { percentage of primary follicles via dysregulation of } \\
\text { PI3K signaling }\end{array}$ \\
\hline Li et al., 2014 [33] & $\begin{array}{l}\text { Pregnant mice treated with DEHP from } 0 \text { to } \\
40 \mu \mathrm{g} / \mathrm{kg} / \text { day from } 0.5 \text { to the } 18.5 \text { th day post coitum. }\end{array}$ & $\begin{array}{l}\searrow \text { percentage of } \mathrm{CpG} \text { sites in the differentially methylated } \\
\text { regions of the oocytes in } \mathrm{F} 1 \text { mice, heritable to F2. }\end{array}$ \\
\hline Zhang et al., 2015 [32] & $\begin{array}{l}\text { Pregnant mice exposed to DEHP, evaluation of } \\
\text { the ovarian reserve in offspring generations }\end{array}$ & $\begin{array}{l}\text { Delay of meiosis initiation in F1 fetal ovaries with Stra8 } \\
\text { gene hypermethylation and underexpression } \\
\text { Acceleration of follicular recruitment in the F1 and F2 } \\
\text { generations responsible for depletion in the primordial } \\
\text { follicle pool. }\end{array}$ \\
\hline Niermann et al., 2015 [34] & $\begin{array}{l}\text { Pregnant mice exposed to DEHP from } 20 \mu \mathrm{g} \text { to } \\
750 \mathrm{mg} / \mathrm{kg} / \mathrm{day} \text {. Evaluation of the number of follicles } \\
\text { at D8 and D21 and fertility at } 3 \text { and } 9 \text { months. }\end{array}$ & $\begin{array}{l}7 \text { number of pre-antral follicles at D21 with a } \\
\text { non-monotonic dose-effect } \\
22.2 \% \text { of mice exposed in utero to } 20 \mu \mathrm{g} / \mathrm{kg} / \text { day took } \\
\text { more than } 5 \text { days to become pregnant at } 3 \text { months }\end{array}$ \\
\hline Sen et al., 2015 [38] & $\begin{array}{l}\text { Mice exposed to DBP at } 0.01,0.1 \text { and } 1000 \mathrm{mg} / \mathrm{kg} / \text { day } \\
\text { for } 10 \text { days. }\end{array}$ & $\begin{array}{l}\searrow \text { number of antral follicles } \gg \text { mRNA coding for } \\
\text { pro-apoptosis genes }\end{array}$ \\
\hline Li et al., 2016 [36] & $\begin{array}{l}\text { Intraperitoneal injection of DEHP in newborn mice, } \\
20 \text { to } 40 \mu \mathrm{g} / \mathrm{kg} \text {, every } 5 \text { days. }\end{array}$ & $\begin{array}{l}\searrow \text { percentage of antral follicles. } \\
\geqslant \text { mRNA of apoptosis genes. Accumulation of ROS. }\end{array}$ \\
\hline Hannon et al., 2016 [37] & $\begin{array}{l}\text { Oral exposure of adult mice to DEHP ( } 20 \text { or } \\
500 \mathrm{mg} / \mathrm{kg} / \text { day) every day for } 10 \text { days }\end{array}$ & $\begin{array}{l}\geqslant \mathrm{BAX} / \mathrm{BCL} 2 \text { ratio in primordial follicles, } \\
\searrow \text { number of primordial follicles, } 9 \text { months after exposure. }\end{array}$ \\
\hline
\end{tabular}

Human Data

Messerlian et al., 2016 [42] Assay of phthalate metabolites in urine and antral follicle count, prospective study on 215 patients between 2004 and 2012

$\searrow$ antral follicle count in patients whose metabolite assay was in the higher quartiles compared to lower concentrations

messenger RNAs coding for pro-apoptotic genes [37, 39] even at low daily doses [38]. Another study found the same results with a decrease in the number of primordial follicles in addition to an increase in the percentage of primary follicles, suggesting an alteration in the beginning of folliculogenesis by accelerating primordial follicle recruitment [40]. The study on the exposure of DEHP alone or combined with tobacco showed a decrease in the number of ovarian follicles in accordance with mechanisms of apoptosis. No interaction effect was observed on the two toxicants [41].

A prospective human study on 215 patients recruited between 2004 and 2012 demonstrated a significant decrease in antral follicle count in patients whose urinary phthalate level was high compared to lower concentrations [42] after adjusting for age, BMI and smoking. However, this study was conducted on a population of infertile patients and it is difficult to generalize to the whole population.

In summary, we can conclude that phthalates disrupt ovarian function and impact the ovarian reserve by intervening at different stages of folliculogenesis [30].

Bisphenol A (BPA) is an aromatic organic compound found in plastics used for food packaging (such as polycarbonates), epoxy resins (interior coating on metal containers and beverage cans) and temperature sensitive papers (receipts). BPA is mass produced and found ubiquitously throughout the environment. Studies have 
shown that BPA is found in more than $90 \%$ of urine samples in a control population [43] (Table 4).

BPA is an endocrine disruptor acting notably like an estrogen mimicker on the estrogen receptor $\alpha$ [17]. These effects have led French authorities to restrict the use of products containing BPA. Since July 2010, the use of baby bottles containing BPA has been prohibited. Since January 1, 2014, the manufacture and sale of any packaging containing BPA in contact with foodstuff has been prohibited.

The animal data support this argument and highlight a negative effect of BPA on ovarian reserve. In fact, exposure to BPA leads to a decrease in the number of primordial follicles regardless of the exposure window whether it is prenatal $[44,45]$, neonatal [46] or at the adult age [47]. In humans, a prospective study on women seeking care for infertility reported that high urinary BPA concentrations were associated with low antral follicle count after adjusting for age and BMI [48]. These data are supported by the animal and human reviews by Caserta et al. [49], Machtinger and Orvieto [50] and Richardson et al. [17] that conclude that exposure to BPA was associated with a decrease in ovarian reserve.

In utero exposure to BPA alters the ovarian reserve of the F1 generation but the results are not significant concerning the F2 and F3 generations; therefore, the negative effect of BPA does not seem to be transgenerational [44]. Nevertheless, these authors highlighted a modification in the expression of ovarian genes involved in apoptosis and steroidogenesis in later generations from F1 to F3 after in utero exposure to BPA in favor of a transgenerational effect on ovarian gene expression.

Pesticides are chemical compounds used in agriculture to fight against organisms that are considered to be harmful to crops. They are composed of different families such as insecticides, herbicides, fungicides, etc.
These organic elements have properties making them stable and lipophilic, which makes them slow to degrade over time. In this way, they remain in the environment for several years with an extensive presence in soil, food and water.

Many pesticides play the role of an endocrine disruptor in the body, altering reproductive functions and, notably, ovarian function.

The literature analysis on pesticides and POI has allowed collecting data from 6 articles and 3 reviews. The results are described in Table 5. Data was mainly on animals.

Alterations to cell ultrastructure, which are signs of cell apoptosis, are found in cases of exposure of female rats to permethrin, an insecticide in the pyrethroid family [51] or to methyl parathion, insecticide from the organophosphate family [52], leading to an alteration in the total number of follicles.

Exposure to Simazine [53], a herbicide from the triazine family, or to Methoxychlor (MXC) [54] an organophosphate pesticide, led to a decrease in total ovary weight, which is a sign of follicular atresia $[55,56]$. Prenatal exposure to MXC in rats showed modifications to DNA methylation, which suggests epigenetic mechanisms [57].

An epidemiological research was conducted on 8038 female participants living and working on American farms. It showed that the median age at menopause was increased by 3 to 5 months, depending on the types of pesticides used [58]. After controlling for age, smoking status, and past use of oral contraceptives, pesticide use seemed to be associated with a later onset of menopause. In this study, women were exposed to multiple pesticides, which could have minimized the estimation of the effect of a specific one.

Analysis of the articles yielded results from other studies that seemed to highlight a link between exposure to pesticides and an impact on the ovarian reserve.

Table 4 Effect of bisphenol A on ovarian function

\begin{tabular}{ll}
\hline References & Methods \\
\hline Animal Data & \\
Rodríguez et al., 2010 [46] & Neonatal exposure of mice from D1 to D7 to \\
& BPA 0.05 or $20 \mathrm{mg} / \mathrm{kg} /$ day
\end{tabular}

Zhang et al., 2012 [45]

Li et al., 2014 [47]

Berger et al., 2015 [44]
Exposure of pregnant mice at $0.02,0.04$ or $0.08 \mathrm{mg} / \mathrm{kg} /$ day of orally administered BPA from Day 12.5 post coïtum.

Intraperitoneal injection of 10,40 or $160 \mathrm{mg} / \mathrm{kg}$ of BPA in prepubertal rats for 1 week and D21 from F1 to F3
Results

$\nabla$ percentage of primordial follicles $\gg$ percentages of growing follicles at $20 \mathrm{mg} / \mathrm{kg} /$ day dose by increased recruitment, $\gg$ proliferation of granulosa cells at every follicular stage

$\checkmark$ number of primordial follicles at D3 by defaults in assembly associated with. a delay in meiosis I progression $\Downarrow$ mRNA expression of specific meiotic genes

$\searrow$ ovary weight, $\searrow$ number of primordial follicles at the highest dose, dose -dependant $\nabla$ in numbers of total, primary/preantral and antral follicles, $\gg$ number of atretic follicles

Alteration in the number of follicles for F1, but not for F2 and F3. Alterations in ovarian gene expression at D21 with a transgenerational effect 
Table 5 Effects of pesticides on ovarian function

\begin{tabular}{|c|c|c|}
\hline References & Methods & Results \\
\hline \multicolumn{3}{|l|}{ Animal Data } \\
\hline Zama and Uzumcu, 2009 [57] & $\begin{array}{l}\text { Prenatal exposure of pregnant rats to MXC } 20 \mu \mathrm{g} \\
\text { or } 100 \mathrm{mg} / \mathrm{kg} / \text { day from embryonic D19 until } \\
\text { postnatal day } 7 .\end{array}$ & $\begin{array}{l}\text { DNA hypermethylation of several ovarian genes among } \\
\text { which ER beta. } \\
\text { DNA methyltransferase 3b (DNMT3b) levels in ovaries } \\
\text { at } 100 \mathrm{mg} / \mathrm{kg} / \text { day }\end{array}$ \\
\hline Park et al., 2014 [53] & $\begin{array}{l}\text { Oral exposure of pregnant mice from gestational } \\
\text { D12 to post-natal day } 20 \text { with } 5 \text { to } 500 \mu \mathrm{gg} / \mathrm{kg} \\
\text { dose of Simazine. }\end{array}$ & $\begin{array}{l}\searrow \text { Ovarian weight and } \gg \text { apoptosis of granulosa cells } \\
\text { in the F1 generation with downregulation of } \\
\text { anti-apoptotic and proliferation genes }\end{array}$ \\
\hline El-Sharkawy et al., 2014 [54] & $\begin{array}{l}\text { Oral exposure of female rats to } 200 \mathrm{mg} / \mathrm{kg} \text { twice } \\
\text { weekly to } \mathrm{MXC} \text { alone, or combined with propolis } \\
\text { (a natural anti-oxydant) } 200 \mathrm{mg} / \mathrm{L} \text { for } 10 \text { months }\end{array}$ & $\begin{array}{l}\searrow \text { Ovarian weight, } \gg \text { atresia of primary, secondary and } \\
\text { antral follicles, } \searrow \text { ovarian antioxidant status and } \gg \text { in } \\
\text { ovarian lipid peroxidation. Toxic effect neutralized } \\
\text { using Propolis }\end{array}$ \\
\hline Satar et al., 2015 [52] & $\begin{array}{l}\text { Oral exposure of adult female rats to methyl } \\
\text { parathion, every day for } 8 \text { days. Followed by } \\
\text { ovarian histological analysis }\end{array}$ & $\begin{array}{l}\text { Structural alteration of the ovarian stroma with } \\
\text { apoptosis phenomena in follicles during chronic } \\
\text { exposure. = Alteration of follicular capital }\end{array}$ \\
\hline Kotil and Yön, 2015 [51] & $\begin{array}{l}\text { Oral exposure of adult rats to permethrine, } 20 \text { or } \\
40 \mathrm{mg} / \mathrm{kg} / \text { day for } 14 \text { days. Ovarian histological } \\
\text { evaluation }\end{array}$ & $\begin{array}{l}\text { Picnotic nucleus, condensed chromatin, alteration } \\
\text { to the mitochondrial structure }\end{array}$ \\
\hline \multicolumn{3}{|l|}{ Human Data } \\
\hline Farr et al., 2006 [58] & $\begin{array}{l}\text { Epidemiological study on } 8038 \text { women who } \\
\text { live and work in rural American }\end{array}$ & $\begin{array}{l}7 \text { median age at menopause by } 3 \text { months }(\mathrm{OR}=0.87 \text {, } \\
\mathrm{Cl} 95 \%=0.78-0.97) \text { and at } 5 \text { months }(\mathrm{OR}=0.77 \text {, } \\
\mathrm{Cl} 95 \%=0.65-0.92) \text { depending on the type of } \\
\text { pesticides used }\end{array}$ \\
\hline
\end{tabular}

In one animal study, exposure of female rats to Maneb, an ethylene bisdithiocarbamate led to a reduction in the number of healthy ovarian follicles due to a dose-dependent follicular apoptosis [59].

One case-control study analyzing data from 1407 women [60], reported an earlier age at menopause for women having a higher plasma concentration of 1,1Dichloro-2,2-bis(4-chlorophenyl)ethene, a dichlorodiphenyldichloroethylene (DDE) isomer when taking several factors into account (age, race, education, parity and lactation, physical activity, thyroid condition, body mass index and smoking).

At the same time, a cross-sectional study [61] in 219 women reported an association between elevated blood levels of specific organochlorines and an earlier age at menopause even after different confounders had been taken into account.

Cigarettes smoke contains more than 4000 chemical substances such as hydrocarbons, alcohols, phenols, aldehydes, heavy metals, etc.

The most studied components of cigarette smoke known to influence female fertility are polycyclic aromatic hydrocarbons (PAHs) which, alone, contain more than 100 chemical substances resulting from incomplete combustion. They act on the ovary via the aryl hydrocarbon receptor (AhR) present on the surface of granulosa cells. This receptor belongs to the family of transcription factors and activates the Bax gene, a pro-apoptosic gene, and the expression of cytochrome P450 that converts PAHs into even more toxic molecules [17, 62, 63].
Anderson et al. have shown that activation of this receptor could lead to a decrease in germ cells in the ovary of the human fetus [64].

All of these substances have a toxic effect on the ovary and on the reproductive function. Active cigarette smoking is associated with longer delays to conceive and with decreased results after assisted reproductive technologies [65].

We have studied the effect of cigarette smoking on POI by analyzing 22 articles, 4 reviews and one metaanalysis (Table 6). We can divide this literature into 3 categories.

Firstly, studies focusing on the relationships between cigarette smoking and age of menopause onset. According to the meta-analysis by Sun et al. [66], cigarette smoking in women is an independent factor for earlier age of menopause. Additionally, systematic reviews by Harlow and Signorello [67] and by Parente et al. [68] show an association between cigarette smoking and the age of menopause onset, but do not provide evidence that duration and quantity of exposure had any association with the age at menopause.

According to a transversal study conducted on a cohort of 24,152 Japanese nurses, cigarette smoking was a factor associated with an earlier onset of natural menopause [69].

Age at menopause is earlier from 0.8 to 1.4 years in patients who smoke according to an epidemiological study on 7596 participants [70]. In another epidemiological study, Tawfik et al. found this association for patients exposed for more than 26 years [71], and there 
Table 6 Effects of tobacco on ovarian function

\begin{tabular}{|c|c|}
\hline References & Methods \\
\hline \multicolumn{2}{|l|}{ Animal Data } \\
\hline Matikainen et al., 2001 [63] & $\begin{array}{l}\text { Adult mouse exposure to a single intraperitonea } \\
\text { injection of 9,10-dimethylbenz[a]anthracene } \\
\text { (DMBA) } 50 \mathrm{mg} / \mathrm{kg} \text {, a typical PAH }\end{array}$ \\
\hline Jurisicova et al., 2007 [78] & $\begin{array}{l}\text { Exposure of mice to } 2 \text { PAHs (DMBA and } \mathrm{BaP}) \\
3 \text { weeks before gestation and during lactation }\end{array}$ \\
\hline Paixão et al., 2012 [79] & $\begin{array}{l}\text { Exposure of } 10 \text { mice to cigarette smoke } 8 \text { h/day } \\
7 \text { days/week for } 15 \text { days. Euthanized at the end } \\
\text { of exposure or } 30 \text { days after. }\end{array}$ \\
\hline
\end{tabular}

Kilic et al., 2012 [76]

Gannon et al., 2012 [77]

Sobinoff et al., 2013 [65]

Lim et al., 2013 [89]

Camlin et al., 2016 [82]

\section{Human Data}

Progetto Menopausa Italia Study Group, 2003 [74]

Chang et al., 2007 [72]

Kinney et al., 2007 [110]

Strohsnitter et al., 2008 [84]

Fleming et al., 2008 [70]

Freour et al., 2008 [81]

Lutterodt et al., 2009 [87]

Ernst et al., 2012 [86]

(Yasui et al., 2012)

Fraser et al., 2013 [83]
Prospective randomized study, 25 pregnant rats exposed or unexposed to cigarette smoke.

Mice exposed to tobacco smoke 5 day/week, for 4, 8, 9 or 17 weeks.

Nasal exposure of mice to cigarette smoke. Ovarian toxicity analysis $10 \mathrm{mg} / \mathrm{kg} / \mathrm{d}$ from the 7 th to 16 th gestational day. Effect of polymorphism of glutamate cysteine ligase

Nasal exposure of pregnant mice to cigarette smoke for 12 weeks. Analysis of F1 ovary and oocyte quality
Inclusion of patients between ages 45 to 75 for menopause in Italy between 45 and 60 years and FSH in 188 patients aged 22 to 49 years and age at menopause and FSH levels in the blood

Analysis of 111 patients treated for infertility

Ovary analysis of 29 fetuses in the 1st trimester. Ovary analysis, compared to maternal cigarette smoking exposure

Prospective study on 965 pregnant women at 30 weeks amenorrhea. Evaluation of maternal cigarette smoking and study in 2008 on the fertility of their daughter $(n=438)$ nurses, research on factors associated with $\mathrm{POI}$
Mouse exposed by gavage to $\mathrm{B}[\mathrm{a}] \mathrm{P}$ at 0.2 or

Results

Activation of the aromatic hydrocarbon receptor (Ahr) driving Bax expression in oocytes, a pro-apoptosis factor

$\checkmark$ by one third of the ovarian follicle pool in F1 compared to unexposed offspring

Alteration in follicular growth even after discontinuing the exposure.

$\searrow$ Number of granulosa cells in the exposed group

significant $\gg$ in DNA anomalies and the apoptotic index in the ovaries of exposed group $\Downarrow$ offspring ovarian reserve

$\searrow$ ovary weight and number of primordial follicles. $\gg$ oxidative stress. BCl-2 expression $\searrow$ but apoptosis was not induced

$\gg$ Depletion of primordial and antral follicular stock via, mechanisms of apoptosis and oxidative stress

Prenatal exposure to BaP induced POI. Deletion of glutamate cysteine ligase increased the sensitivity of these ovarian effects

Abnormal proliferation of neonatal somatic cells, $\gg$ apoptosis, $\searrow$ follicles at birth and at the adult age.

$\gg$ oxidative stress

No significant association between the risk of POI and smoking making a 1st consultation in a specialized center

Study of risk factors in 137 menopausal patients $<40$ years, 281 between 40 and 4 years, and 1318

Effect of cigarette smoking on antral follicle count

Epidemiological study on 4025 women. Association between prenatal exposure to cigarette smoking

Epidemiological study on 7596 women. Cotinine

Transversal study of a cohort of 24,152 Japanese

Analysis of a cohort of 1399 adolescents between 1991 and 2008. Study on AMH levels depending on parental exposure to cigarette smoking
Smoking $\gg$ the idiopathic risk of $\mathrm{POI}: \mathrm{OR}=1.82$ [1.03-3.23]

Chronic cigarette smoking is associated with higher rates of $\mathrm{FSH} \beta=0.21,95 \% \mathrm{Cl}=0.04,0.39$, but there is no significant difference on the AFC

An association between prenatal exposure and age at menopause for patients who have never smoked ( $H R=1.38,95 \% \mathrm{Cl}: 1.10,1.74)$. Not found in patients who smoke $(\mathrm{HR}=1.03,95 \% \mathrm{Cl}: 0.81,1.31)$

Average age at menopause $=47.17$ years for smokers compared to 48.59 years for non-smokers.

Significant $\searrow$ of $\mathrm{AMH}$ levels in patients who smoke $3.06+/-1.68 \mathrm{mg} / \mathrm{L}$, compared to 3.86 +/- 1.92

$\searrow$ number of somatic cells $(P \leq 0.01)$. Number of oogonia not associated with prenatal exposure to maternal cigarette smoking $(P \leq 0.09)$

No significant association between in utero cigarette smoking exposure and the number of follicles

Cigarette smoking is associated with an earlier age at menopause

Paternal, and not maternal, cigarette smoking before and during pregnancy is associated with a decrease in $\mathrm{AMH}$ levels. 
Table 6 Effects of tobacco on ovarian function (Continued)

\begin{tabular}{|c|c|c|}
\hline Caserta et al., 2013 [80] & $\begin{array}{l}\text { Analysis of the antral follicle count and FSH levels in } \\
296 \text { women, including } 102 \text { smokers }\end{array}$ & $\begin{array}{l}\searrow \text { Antral follicle count and } \geqslant \text { FSH in cigarette } \\
\text { smokers correlated to the number of pack-years. }\end{array}$ \\
\hline Fowler et al., 2014 [85] & $\begin{array}{l}\text { Analysis of } 105 \text { fetuses resulting from elective } \\
\text { terminations in the } 2 \text { nd trimester, } 56 \text { exposed, } \\
49 \text { unexposed. }\end{array}$ & Dysregulation of fetal ovarian signaling pathways \\
\hline Butts et al., 2014 [88] & $\begin{array}{l}\text { Survival analysis for a cohort of } 410 \text { patients. } \\
\text { Nucleotide polymorphism study }\end{array}$ & $\begin{array}{l}\text { Risk of early menopause in cigarette smokers } \\
\text { depends on genetic polymorphism. }\end{array}$ \\
\hline Tawfik et al., 2015 [71] & $\begin{array}{l}\text { Cohort study of } 1001 \text { women aged } 39 \text { to } 49 \text { years. } \\
\text { Evaluation of the association between exposure to } \\
\text { cigarette smoke throughout the lifetime (prenatal, } \\
\text { childhood, adulthood) and menopause status }\end{array}$ & $\begin{array}{l}\text { Prenatal exposure and current cigarette smoking: } \\
3 \text { times more risk of early menopause }(3.4 ; 95 \% \mathrm{Cl} \text {, } \\
1.1-10.3) \text {. Long-term exposure ( }>26 \text { years) is } \\
\text { associated to the age at menopause. }\end{array}$ \\
\hline Peck et al., 2016 [73] & $\begin{array}{l}\text { Analysis of primordial follicle stock in } 133 \text { patients } \\
\text { having underwent hysterectomy for a benign } \\
\text { pathology. }\end{array}$ & $\begin{array}{l}\text { No association between follicle count and cigarette } \\
\text { smoking }\end{array}$ \\
\hline \multicolumn{3}{|l|}{ Meta-Analysis } \\
\hline Sun et al., 2012 [66] & $\begin{array}{l}\text { Analysis of } 11 \text { studies } \\
\text { Effect of cigarette smoking on age at menopause }\end{array}$ & $\begin{array}{l}\text { Dichotomous studies: } \mathrm{OR}=0.67(\mathrm{Cl} 95 \%, 0.61 \text { to } 0.73 \text {, } \\
P<0.01) \text {. Continuous studies: } \mathrm{OR}=-0.90(\mathrm{Cl} 95 \%, \\
-1.58 \text { to }-0.21, P<0.01) \\
\text { Cigarette smoking }=\text { independent factor in early } \\
\text { age at menopause }\end{array}$ \\
\hline
\end{tabular}

was three times more risk for early menopause (OR: 3.4; 95\% CI, 1.1-10.3). Cigarette smoking was a risk factor for POI with an odds ratio of 1.8 (1.03-3.23) [72].

One study did not show an association between age at menopause and cigarette smoking, but the authors alluded to selection and recall bias, which may have minimized the role of cigarette smoking in the onset of menopause [73]'[74].

Secondly, others studies focused on the relationships between cigarette smoking and follicle reserve. According to the animal review from Camlin [62], cigarette smoking has negative effects on female fertility. Exposure to tobacco induces a depletion in follicle stock [75-78], according to a mechanism of apoptosis and oxidative stress [75-78]. This depletion in follicle stock seems to persist, even in the case of discontinuing smoking [79]. Only one study highlighted an increase in oxidative stress associated with a decrease in bcl-2 (anti-apoptosis genes) without being able to show a real mechanism of cellular apoptosis (no difference in the proportion of TUNEL positive cells in exposed and non exposed ovarian follicles) [77].

Analysis of human data reinforced this theory: cigarette smoking led to a decrease in antral follicle count [80], an increase in serum FSH levels [72, 80] and a decrease in AMH (anti-mullerian hormone) levels [81] in smokers, and this seems to correlate with the number of pack-years [80]. Only the Peck et al. study [73] did not show an association between cigarette smoking and histological primordial follicle count, but the authors allude to selection bias (inclusion by surgeons, no systematic evaluation by the investigators at inclusion).

Thirdly, some studies scrutinized the effects of cigarette smoking during prenatal exposure. After in utero exposure, the Camlin et al. animal study [82] revealed a decrease in the number of follicles at birth and in adulthood by increasing pro-apoptotic phenomena. A cohort study on 1399 adolescents highlighted that paternal cigarette smoking is associated with decreased rates of $\mathrm{AMH}$ [83]. An association between prenatal tobacco exposure and the age at menopause is found for patients who have never smoked $(\mathrm{HR}=1.38,95 \% \mathrm{CI}$ : $1.10,1.74)$. However, this association is no longer found in patients who smoke $(\mathrm{HR}=1.03,95 \% \mathrm{CI}$ : $0.81,1.31)$ [84]. Therefore it seems that in utero exposure to cigarette smoking dysregulates fetal ovarian development signaling [85]. However, two human studies [86, 87], were unable to show a significant association between in utero cigarette smoking and the number of follicles in adulthood.

The monitoring of a cohort of 410 patients was suggestive of an interaction of genetic polymorphism with the environment. In fact, the risk of POI in cigarette smokers depended on genetic polymorphism [88]. This ovarian sensitivity, variable depending on genetic background, is shown in the murine study by Lim et al. [89], where POI induced by in utero $\mathrm{B}[\mathrm{a}] \mathrm{P}()$ exposure was increased by deletion of the glutamate cysteine ligase gene.

Phytoestrogens are plant-derived natural substances that have the particularity of mimicking the action of estrogens on their receptors (for review see [90]). The primary sources are isoflavones, of which the most common one is genistein, or lignans. An animal study has allowed studying the effect of exposure of the soy isoflavone on female rats from weaning to sexual maturity. This substance altered follicular development by increasing apoptosis of granulosa cells [91]. Neonatal exposure 
of mice to genistein seemed to confer early senescence of the ovarian function [92], over several generations [93] (Table 7).

A review of the literature on phytoestrogens suggested a disturbance in ovarian function and folliculogenesis without specifying the effect on the ovarian reserve [94]. However the review by Patel et al. [95] specified that genistein was responsible for a decrease in primordial, primary and secondary follicles with an increase in antral follicles. This acceleration of follicular recruitment is combined with an increase in apoptosis, and finally, follicular atresia.

Polycyclic aromatic hydrocarbons (PAH) are substances resulting from the incomplete combustion of organic fossil or non-fossil materials; one of the main components is $\mathrm{B}[\mathrm{a}] \mathrm{P}$. This is a large family that includes certain furans, dioxins and polychlorinated biphenyls (PCB). They act by modulating the transcription of the $\mathrm{AhR}$ gene and have effects on reproduction [96].

Dioxins are environmental contaminants belonging to the PAH family. They mainly result from waste incineration and act via $A h R$, for which they are ligands. 2,3,7,8-tetrachlorodibenzo-p-dioxin (TCDD) is the most toxic member of the dioxin family [97]. It has a long half-life and accumulates in the environment and in the tissues of living organisms [98, 99].

The review of Patel et al. [95] specified that the ovary was a clear target for TCDD, altering folliculogenesis. Chronic exposure to low doses of TCDD is associated with chronic activation of AhR [96], a depletion in follicle stock that contributes to premature ovarian senescence in rats [100]. An epidemiological study from 616 Italian non menopausal women exposed to the Seveso explosion found a significant trend for an earlier age at menopause in the four first quintiles of level of exposure to TCDD at the time of explosion but not for the 5 quintiles, suggesting a nonmonotonous dose-related effect [101]. The data were adjusted for several covariates (education, parity, duration of oral contraception use).

Polychlorinated biphenyls (PCB) belong to the PAH family; there are 209 isomers resulting from complex industrial processes. They have been banned since the 1970s, but, because of their stability in the environment, they persist in adipose tissues, living organism fluids and in food (for review see [102]). They can lead to direct and indirect effects on ovary function [103]. Maternal exposure to PCB seems to have consequences on offspring, with a decrease in ovary weight in the offspring [104] and follicular atresia [105].

Perfluorinated compounds are a large family of chemical substances present in industry and everyday consumer products, notably for their anti-adhesive and anti-grease properties. They are very resistant to degradation and persist in the environment and in the food chain [106]. Two large scale epidemiological studies have demonstrated confounders-adjusted associations between exposure to perfluorinated compounds and an earlier age at menopause $[107,108]$.

A review led in the context of the American National Toxicology Program showed that women exposed to 2bromopropane are at risk for the early onset of menopause [109].

Finally, other toxicants such as alcohol [73, 110], flame retardants [111], diesel [112] or anti-UV protectors [113] seem to influence the ovarian reserve but we have not found sufficient data to conclude this. Indeed, only animal studies are available for flame retardants [111], diesel [112] and anti-UV protectors [113] and discrepancies exist between the two human cross-sectional studies for alcohol $[73,110]$.

\section{Discussion}

POI is a pathology in young women that can alter their fertility and, more generally, their quality of life. Its idiopathic etiology (75\% of cases) could be explained by the fact that the state of ovarian reserve at a given time seems to reflect a multifactorial influence combining factors that are genetic, epidemiological and environmental in nature [114].

One of the strengths of this review may be its original nature. This is because most data available have studied the general effect of environmental pollutants on the ovary, without focusing on the mechanisms that could lead to POI. A substantial number of articles were analyzed.

The limits of this review are that most of the data have shown follicular atresia, a decrease in ovarian reserve or even an earlier age at menopause onset. Even though all of these components help create a picture of POI, they do not define POI itself. This point leads to another limit of our study that consists in the lack of systematic evaluation of the quality of evidences depicted in the studies, notably regarding the evidence for causal relationships between EDC exposures and POI. As such, our review cannot be described as a systematic review. It is noteworthy that except for tobacco smoke exposure, we couldn't find articles reporting no association between exposure to an EDC and POI (or a witness of future POI) but this could be linked to publication bias since positive results are more likely to be published than those with negative findings (no effect of an EDC), as recently admitted by the US Endocrine Society [115].

Our review reinforces the notion that the environment, and in particular, substances acting as endocrine disruptors, seem to play a key role in the onset of mechanisms likely to cause POI. The four mechanisms leading to POI depicted in Fig. 1 can be ranked by descending order. Firstly, the induction of follicular atresia during follicular growth via an increase in oxidative stress and apoptotic phenomena (referred as situations 2 
Table 7 Effects of various pollutants on ovarian function

\begin{tabular}{ll}
\hline References & Methods \\
\hline Phytoestrogens & $\begin{array}{l}\text { Oral or subcutaneous exposure of neonatal mice } \\
\text { to genistein }(0.5-50 \mathrm{mg} / \mathrm{kg})\end{array}$ \\
Jefferson et al., 2007 [92] &
\end{tabular}

Kim and Park, 2012 [94]

Wang et al., 2014 [91]

PAH

Hombach-Klonisch et al., 2005 [96] Review of the PAHs

Dioxins

Eskenazi et al., 2005 [101]

Shi et al., 2007 [100]

PCB

Shirota et al., 2006 [104]

Pocar et al., 2012 [105]

Perfluorinated compounds

Knox et al., 2011 [108]

Taylor et al., 2014 [107]

Alcohol

Peck et al., 2016 [73]

Flame retardants

Lefèvre et al., 2016 [111]

$\mathrm{HMB}=2$-hydroxy-4methoxybenzone, anti-UV protector

Nakamura et al., 2015 [113]

Rats exposed to different doses of HMB (7-8 per group) from the 6 th gestational day until the $23 \mathrm{rd}$ postnatal day. Effects on offspring

Diesel

Ogliari et al., 2013 [112]
Review of the effect of phytoestrogens on sexual function

Rats orally exposed to 50,100 or $200 \mathrm{mg} / \mathrm{kg}$ of soy isoflavones from weaning to sexual maturity and evaluation of the ovarian reserve

Epidemiological study conducted for 20 years on a city in Italy contaminated with TCDD following an industrial explosion. 616 patients included, impact of TCDD serum levels on age at menopause

Chronic exposure at low doses $(0,1,5,50$ or $200 \mathrm{ng} / \mathrm{kg} /$ week) in female rats to TCDD from in utero life until ovarian senescence

Oral exposure in female rats to PCB 126 at 0,1 or $3 \mu \mathrm{g} / \mathrm{kg} /$ day for 2 weeks before mating until birth

Exposure of mice to a mixture of PCB $0,1,10$ or $100 \mathrm{mg} / \mathrm{kg} /$ day during pregnancy and lactation

Cross-sectional study on 25,957 women

Cross-sectional study of the NHANES cohort, 3011 women were studied for the association between exposure to perfluorinated compounds and the age at menopause onset

Analysis of primordial follicle stock in 133 patients having underwent hysterectomy. Evaluation of behavioral habits using a questionnaire

Exposure of pregnant rats to bromine flame retardants for 2 to 3 weeks
Results

Early senescence of the ovarian function, multigenerational effect, $\gg$ multi-oocyte follicles from defaults in primordial follicles assembly,ovulation rates and corpora lutea at low doses and anovulation at the highest dose with arguments for disruption of the hypothalamic-pituitary-gonadal axis

Disruption of ovarian function and folliculogenesis. No specification on the consequences on the ovarian reserve

Alteration of follicular development by inducing apoptosis of granulosa cells via Fas-mediated and Bcl2/Bax-mediated apoptotic pathways.

Disrupts ovarian function by modulating AhR transcription

$\gg$ in $6 \%$ nonsignificant risk of menopause occurring earlier with high serum concentrations of TCDD. But the trend for early menopause in the first four quintiles is statistically significant

Doses from 50 to $200 \mathrm{ng} / \mathrm{kg} /$ week:

》Follicular depletion and early ovarian senescence, mediated by AhR

$\checkmark$ ovary weight $\gg$ antral follicular atresia in F1 at doses of $3 \mu \mathrm{g} / \mathrm{kg} / \mathrm{d}$. Activation of the AhR system.

PCB level significantly $\gg$ in exposed newborns compared to the controls.

Decrease in ovary weight $(p<0.05)$,

$\gg$ follicular atresia $(p<0.0001)$ in the F1 generation only

Start of menopause was earlier by several months in exposed patients

Women with elevated perfluorinated compound serum levels were younger at menopause than women with lower levels.

Light to moderate alcohol consumption is associated with a higher follicle count.

$\gg 50 \%$ in the number of antral and pre-antral follicles $=$ Alteration of folliculogenesis

Delayed follicular development in the group receiving the highest dose. Exposure at less than 10,000 ppm of HMB does not seem to be associated with adverse effects on the reproductive system

$\searrow$ Number of follicles, $\searrow$ ovarian reserve 
Table 7 Effects of various pollutants on ovarian function (Continued)

\begin{tabular}{lll}
\hline 2-Bromopropane & American review conducted in the context of \\
Boekelheide et al., 2004 [109] & $\begin{array}{l}\text { Four studies in favor of an excess risk of POI } \\
\text { data from five human studies }\end{array}$ & $\begin{array}{l}\text { and one study without excess risk but lacks } \\
\text { strength }\end{array}$
\end{tabular}

and 3 in Fig. 1). This has been shown for numerous substances: BPA [47], phthalates (DEHP [39, 41], DBP [38]), PAH [41, 96], cigarette smoke $[65,76,77,79$, 82], pesticides [51-54], dioxins [100], genistein [91], PCB [104]. Secondly, a decreased pool of primordial follicles (situation 5 in Fig. 1) can originate from its massive atresia consecutive to exposures to PAHs [78], DEHP [37] or cigarette smoke [65, 77] or from a default in its assembly in the fetal ovary as shown for genistein [92] and BPA [45]. Thirdly; an increase in the recruitment of primordial follicles (situation 4 in Fig. 1) has been reported only for phthalates (DEHP [32, 35, 40]) and BPA [46]. Finally, we could not find any example of environmental pollutant whose exposure leads to an arrest at a particular stage of folliculogenesis (situation 6 in Fig. 1).

We found evidence for several molecular pathways involved in the different mechanisms leading to POI, several ones are retrieved from this review. These pathways are presented in Fig. 3. The first one encompasses an endocrine disrupting effect via the two most suspected receptors for hydrophic substances such as most EDCs: the ERs and the AhR systems. An activation of AhR system is involved in the apoptotic processes affecting follicles once activated from the primordial follicles pool due to exposure to PAH [96], dioxins [100], PCB 126 [104] or in those affecting oocytes after PAH exposure [63]. Strikingly, most of the animal studies on the ovarian consequences of exposure to EDCs known to interfere with ERs (such as phthalates, BPA, phyto-estrogens) have not demonstrated that they work via their ERs. This is probably due to the large body of evidence for such interactions reported by many in vitro studies on diverse follicular stages in several mammalian species. Since knockout animals for ER (alpha and beta) display severe ovarian phenotypes, they are useless for such demonstrations that ideally require a positive control (ex: diethylstilbestrol, ER agonist) and the absence of the EDCs effect when using a specific antagonist of the studied ER. The second molecular pathway used by environmental pollutants to influence the risk of POI resides on imbalance between oxidative defenses and the oxidative stress leading to apoptosis. Although we previously discussed the importance of those mechanisms in the altered follicular growth observed after exposure to numerous toxicants, little is known about the precise ways they are induced. Expression of typical markers of apotosis (Bax, $\mathrm{Bcl} 2)$ or measurements of apoptosis- related cellular damages are used as witnesses of apoptosis, but without experimental data showing an excess charge of reactive oxygen species and/or insufficient antioxidant defenses. Because of the threat of a transgenerational inheritance of the defects suspected with EDCs, more detailed attention has been paid to a third mechanism by which environmental pollutants can impact folliculogenesis: epigenetics alterations. Indeed, since folliculogenesis starts during fetal development, it has been established that environmental exposure and the mother's lifestyle can have a direct impact on the ovarian reserve of the two subsequent generations, and even beyond if epigenetic alterations affecting the germline lead to a transgenerational effect. However, although some authors showed epigenetic alterations (in term of DNA methylation exclusively) in the ovarian cells of F1 female offspring exposed to an EDC in utero [57], very few looked into F1 oocytes [32, 33], only one confirmed the alteration in F2 oocytes [33] and none looked into F3 oocytes to demonstrate the transgenerational phenotype. Furthermore, although exposure to BPA in utero leads to a transgenerational effect on ovarian gene expression in F3, folliculogenesis and estradiol secretion were normal [44]. Therefore, in the limit of our selection criteria, because altered methylation levels in F2 oocyte or altered ovarian gene expression in F3 are not indisputable proof of altered folliculogenesis in F3 ovaries, there is no evidence for an ovarian dysfunction caused by environmental pollutant with a true transgenerational inheritance. Finally, the last molecular pathway that environmental pollutants can use involves perturbations in signaling pathways known to influence folliculogenesis. For example, the phosphatidylinositol 3-kinases (PI3K) pathways are known to be regulators of primordial follicle recruitment [116]. The increased activation of primordial follicles toward primary follicles observed after adult mice exposure to DEHP has been shown to be associated with the increased expression of proteins that activate the PI3K pathway and decreased expression of genes that inhibit it [40]. Finally, apart from these different mechanisms by which EDCs could directly affect the ovaries and lead to POI, indirect mechanisms due to hypothalamo-pituitary axis dysfunctions induced by EDCs must be cited although we could not find clear data to confirm this point.

This review clearly demonstrates the lack of human data available on the subject, except for studies on cigarette smoking, which is an independent risk factor in 


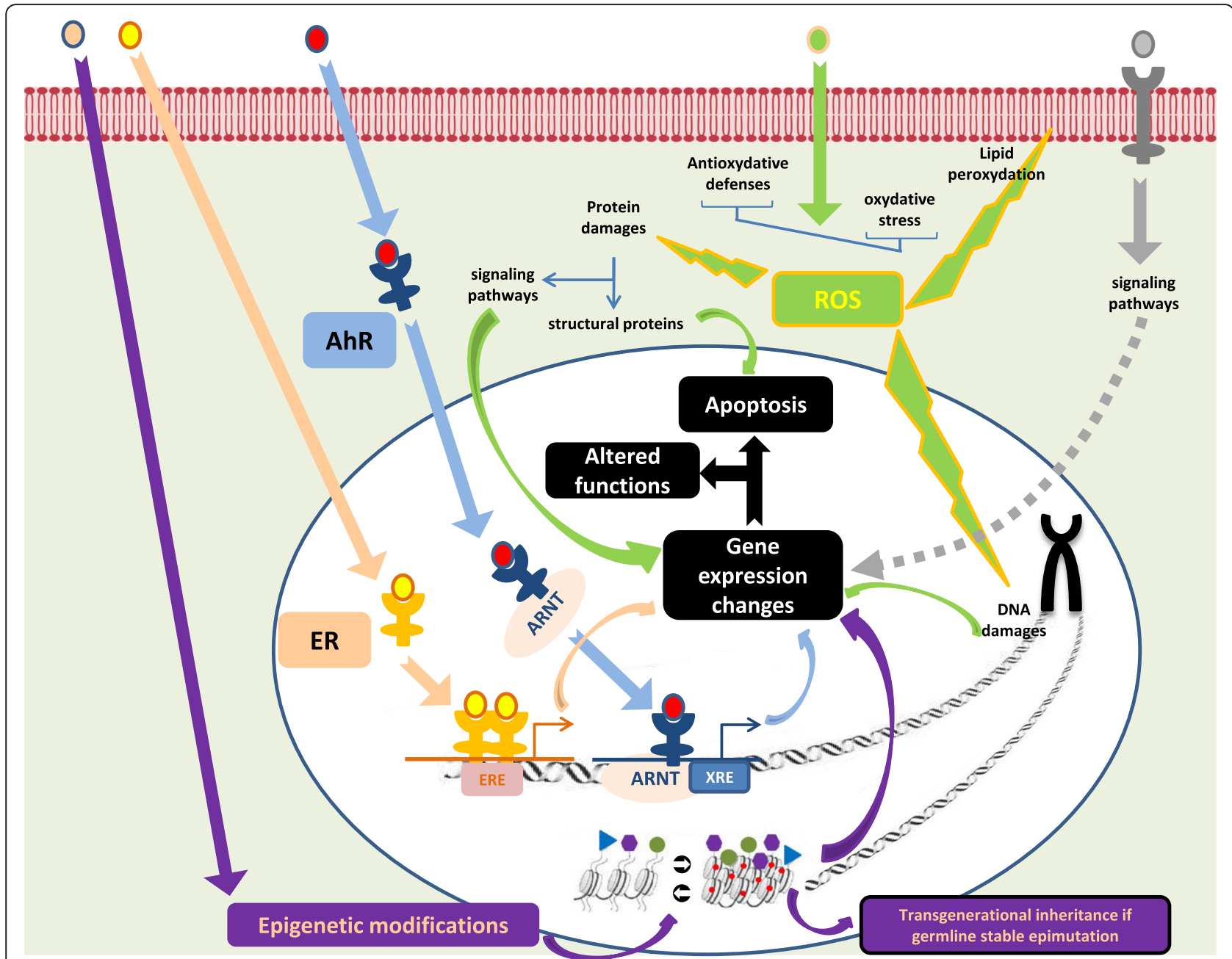

Fig. 3 The major ways used by environmental pollutants to induce defaults in folliculogenesis leading to POI. Environmental pollutants can act through several mechanisms. • actions as endocrine disruptors as ligands to nuclear estrogen receptors (ER, salmon arrows) and aryl hydrocarbon receptors (AhR, blue arrows). Once linked to AhR, they can bind to AhR nuclear translocator (ARNT) to interfere with xenobiotoc responsive elements (XRE) from promotors and affect gene expression, notably promoting pro-apoptotic genes and inhibiting anti-apopototic genes. $\bullet$ creation of an imbalance between oxydative defenses and oxydative stress favoring apoptosis at different follicular stages (green arrows). Modification of epigenetic marks such as DNA methylation $(\bullet)$ or histones post-traductional modifications $(\bullet, \mathbf{0}, \bullet$ affecting the transcriptional state of chromatin and therefore gene expression. binding to several membrane receptors suchs as membrane bound ER (mER) or receptor protein tyrosine kinases (RPTK) activating the PI3 Kinase pathway are suspected (grey dotted arrows)

the occurrence of POI. It also underlines the difficulty in establishing a link in humans between POI and the environment.

This difficulty could be explained by several phenomena. Firstly, exposure to a single toxicant can yield different effects depending on dose and window of exposure. Our review provides a pertinent example of this problem. In rodents, prenatal exposure to BPA affects assembly of primordial follicles in the fetal ovary [45], neonatal exposure increases the activation of follicle growth from the pool of primordial follicles [46] while prepubertal exposure increases atresia in growing follicles [47]. Secondly, human beings are subject to a complex multi-exposure to different environmental pollutants that vary over time and space making it difficult to predict the effects of one specific substance on human health [75]. This is the exposome concept [117]. Depending on these combinations, there can be a cumulative, an antagonistic or a synergy of effects that decreases the ability to detect a significant association between an exposure and the effect on POI [27]. Finally, the quantity and duration of the exposure are difficult to determine in human studies. Many substances, sometimes banned for many years, persist over the long-term and lead to chronic, ubiquitous exposure at low doses.

Beyond well identified genetic anomalies, the genetic context probably plays a role in ovarian susceptibility to environmental pollutants. However, according to some 
authors, arguments based on monozygotic twins cohort studies can suggest that the exposome plays a more important role than genetics in the onset of certain chronic human diseases [118].

\section{Conclusions}

Environmental pollutants are a serious threat to human and animal reproduction with harmful effects that disturb endocrine and reproductive functions. This is a critical public health problem that needs the implementation of protection, prevention and information measures in order to fight against these environmental pollutants. One of these preventive activities may be to help health professionals to better detect patients at risk of POI in order to inform them about their reproductive ability, to limit aggravating factors and to treat them as early as possible through oocyte cryopreservation.

\section{Abbreviations}

AhR: Aryl hydrocarbon receptor; AMH: Anti-mullerian hormone; B[a]P: benzo[a]pyrene; BPA: Bisphenol A;

DDE: dichlorodiphenyldichloroethylene; DEHP: di(2-ethylhexyl)phthalate; DNA: deoxyribonucleic acid; EDCs: Endocrine disruptors; ERs: Estrogen receptors; ESHRE: European Society of Human Reproduction and Embryology; FSH: Follicle stimulating hormone; MEHP: Mono(2ethylhexyl)phthalate; MXC: Methoxychlor; NHANES: National Health and Nutrition Examination Survey; PAH: Polycyclic aromatic hydrocarbons; PCB: Polychlorinated biphenyl; PI3K: Phosphatidylinositol 3-kinases; POI: Premature ovarian insufficiency; PRISMA: Preferred reporting items for systematic reviews and meta-analyses; RNA: Ribonucleic acid; ROS: Reactive oxygen species

\section{Acknowledgements}

No acknowledgement for this study.

\section{Funding}

There was no funding for this study.

\section{Authors' contributions}

All authors were involved in reading referenced papers and writing the manuscript, RL conceived the figures. PV; NG and JM have more specifically reviewed human studies, VG and NHP the animal studies, RL the BPA studies and JP conceived the review. All authors read and approved the final manuscript.

\section{Competing interests}

The authors declare that they have no competing interests.

\section{Consent for publication}

Not applicable (review of published papers).

\section{Ethics approval and consent to participate}

Not applicable (review of published papers).

1. Data sharing not applicable to this article as no datasets were generated or analysed during the current study.

\section{Publisher's Note}

Springer Nature remains neutral with regard to jurisdictional claims in published maps and institutional affiliations.

\section{Author details}

'Médecine de la Reproduction, CHU de Toulouse, Hôpital Paule de Viguier, 330 avenue de Grande Bretagne, F-31059 Toulouse Cedex, France.

2Université de Toulouse; UPS; Groupe de Recherche en Fertilité Humaine (EA 3694, Human Fertility Research Group), F-31059 Toulouse, France. ${ }^{3}$ Institut National de Recherche Agronomique, Unité Mixte de Recherche 1331,
Toxalim, Research Center in Food Toxicology, F-31027 Toulouse, France. ${ }^{4}$ Université de Toulouse, Institut National Polytechnique de Toulouse, Ecole Nationale Vétérinaire de Toulouse, Ecole d'Ingénieurs de Purpan, Université Paul Sabatier, F-31076 Toulouse, France.

Received: 6 October 2016 Accepted: 22 March 2017

Published online: 07 April 2017

\section{References}

1. Buck Louis GM, Sundaram R, Schisterman EF, Sweeney AM, Lynch CD, Gore-Langton RE, et al. Persistent environmental pollutants and couple fecundity: the LIFE study. Environ Health Perspect. 2013;121:231-6.

2. Gascon M, Vrijheid M, Nieuwenhuijsen MJ. The built environment and child health: an overview of current evidence. Curr Environ Health Rep. 2016;3(3):250-57.

3. Haruty B, Friedman J, Hopp S, Daniels R, Pregler J. Reproductive health and the environment: Counseling patients about risks. Cleve Clin J Med. 2016;83:367-72.

4. Le Cann P, Bonvallot N, Glorennec P, Deguen S, Goeury C, Le Bot B. Indoor environment and children's health: recent developments in chemical, biological, physical and social aspects. Int J Hyg Environ Health. 2011;215:1-18.

5. Barnes SK, Ozanne SE. Pathways linking the early environment to long-term health and lifespan. Prog Biophys Mol Biol. 2011;106:323-36.

6. Landrigan PJ, Miodovnik A. Children's health and the environment: an overview. Mt Sinai J Med. 2011:78:1-10.

7. Eshre Guideline Group on Premature ovarian insufficiency, Webber L, Davies M Anderson R, Bartlett J, Braat D, et al. ESHRE Guideline: management of women with premature ovarian insufficiency. Hum Reprod. 2016;31:926-37.

8. Depmann M, Eijkemans MJ, Broer SL, Scheffer GJ, van Rooij IA, Laven JS, et al. Does anti-Mullerian hormone predict menopause in the general population? Results of a prospective ongoing cohort study. Hum Reprod. 2016;31:1579-87.

9. Beck-Peccoz P, Persani L. Premature ovarian failure. Orphanet J Rare Dis. 2006;1:9.

10. Goswami D, Conway GS. Premature ovarian failure. Horm Res. 2007:68:196-202.

11. Qin Y, Jiao X, Simpson JL, Chen ZJ. Genetics of primary ovarian insufficiency: new developments and opportunities. Hum Reprod Update. 2015;21:787-808.

12. Iorio R, Castellucci A, Ventriglia G, Teoli F, Cellini V, Macchiarelli G, et al. Ovarian toxicity: from environmental exposure to chemotherapy. Curr Pharm Des. 2014:20:5388-97.

13. Dragojevic-Dikic S, Vasiljevic M, Nikolic B, Pazin V, Tasic L, Jurisic A, et al. Premature ovarian failure: immunological aspects and therapeutic strategies Vojnosanit Pregl. 2013;70:1051-5.

14. Jin M, Yu Y, Huang H. An update on primary ovarian insufficiency. Sci China Life Sci. 2012;55:677-86.

15. Santulli P, de Villardi D, Gayet V, Lafay Pillet MC, Marcellin L, Blanchet V, et al. Decreased ovarian reserve in HIV-infected women. AIDS. 2016;30:1083-8.

16. Cramer DW, Welch WR, Cassells S, Scully RE. Mumps, menarche, menopause, and ovarian cancer. Am J Obstet Gynecol. 1983;147:1-6.

17. Richardson MC, Guo M, Fauser BC, Macklon NS. Environmental and developmental origins of ovarian reserve. Hum Reprod Update. 2014;20:353-69

18. Craig ZR, Wang W, Flaws JA. Endocrine-disrupting chemicals in ovarian function: effects on steroidogenesis, metabolism and nuclear receptor signaling. Reproduction. 2011;142:633-46

19. Revelli A, Pacchioni D, Cassoni P, Bussolati G, Massobrio M. In situ hybridization study of messenger RNA for estrogen receptor and immunohistochemical detection of estrogen and progesterone receptors in the human ovary. Gynecol Endocrinol. 1996;10:177-86.

20. Fowler PA, Anderson RA, Saunders PT, Kinnell H, Mason II, Evans DB, et al. Development of steroid signaling pathways during primordial follicle formation in the human fetal ovary. J Clin Endocrinol Metab. 2011;96:1754-62.

21. Luderer U. Ovarian toxicity from reactive oxygen species. Vitam Horm. 2014:94:99-127.

22. Tokmak A, Yildirim G, Sarikaya E, Cinar M, Bogdaycioglu N, Yilmaz FM, et al. Increased oxidative stress markers may be a promising indicator of risk for primary ovarian insufficiency: a cross-sectional case control study. Rev Bras Ginecol Obstet. 2015:37:411-6.

23. Uzumcu M, Zama AM, Oruc E. Epigenetic mechanisms in the actions of endocrine-disrupting chemicals: gonadal effects and role in female reproduction. Reprod Domest Anim. 2012;47 Suppl 4:338-47. 
24. Nilsson E, Larsen G, Manikkam M, Guerrero-Bosagna C, Savenkova MI, Skinner MK. Environmentally induced epigenetic transgenerational inheritance of ovarian disease. PLoS One. 2012;7:e36129.

25. Manikkam M, Guerrero-Bosagna C, Tracey R, Haque MM, Skinner MK Transgenerational actions of environmental compounds on reproductive disease and identification of epigenetic biomarkers of ancestral exposures. PLoS One. 2012;7:e31901.

26. Moher D, Shamseer L, Clarke M, Ghersi D, Liberati A, Petticrew M, et al. Preferred reporting items for systematic review and meta-analysis protocols (PRISMA-P) 2015 statement. Syst Rev. 2015;4:1

27. Grindler NM, Allsworth JE, Macones GA, Kannan K, Roehl KA, Cooper AR. Persistent organic pollutants and early menopause in U.S. women. PLOS One. 2015:10:e0116057.

28. Beranger R, Hoffmann P, Christin-Maitre S, Bonneterre V. Occupational exposures to chemicals as a possible etiology in premature ovarian failure: a critical analysis of the literature. Reprod Toxicol. 2012;33:269-79.

29. Heudorf U, Mersch-Sundermann V, Angerer J. Phthalates: toxicology and exposure. Int J Hyg Environ Health. 2007;210:623-34.

30. Hannon PR, Flaws JA. The effects of phthalates on the ovary. Front Endocrinol. 2015;6:8.

31. Moyer B, Hixon ML. Reproductive effects in F1 adult females exposed in utero to moderate to high doses of mono-2-ethylhexylphthalate (MEHP). Reprod Toxicol. 2012;34:43-50.

32. Zhang XF, Zhang T, Han Z, Liu JC, Liu YP, Ma JY, et al. Transgenerational inheritance of ovarian development deficiency induced by maternal diethylhexyl phthalate exposure. Reprod Fertil Dev. 2015;27:1213-21.

33. Li L, Zhang T, Qin XS, Ge W, Ma HG, Sun LL, et al. Exposure to diethylhexyl phthalate (DEHP) results in a heritable modification of imprint genes DNA methylation in mouse oocytes. Mol Biol Rep. 2014:41:1227-35.

34. Niermann S, Rattan S, Brehm E, Flaws JA. Prenatal exposure to di-(2ethylhexyl) phthalate (DEHP) affects reproductive outcomes in female mice. Reprod Toxicol. 2015;53:23-32.

35. Zhang XF, Zhang LJ, Li L, Feng YN, Chen B, Ma JM, et al. Diethylhexyl phthalate exposure impairs follicular development and affects oocyte maturation in the mouse. Environ Mol Mutagen. 2013;54:354-61.

36. Li L, Liu JC, Lai FN, Liu HQ, Zhang XF, Dyce PW, et al. Di (2-ethylhexyl) phthalate exposure impairs growth of antral follicle in mice. PLoS One. 2016;11:e0148350

37. Hannon PR, Niermann S, Flaws JA. Acute exposure to Di(2-eEthylhexyl) phthalate in adulthood causes adverse reproductive outcomes later in life and accelerates reproductive aging in female mice. Toxicol Sci. 2016;150:97-108

38. Sen N, Liu X, Craig ZR. Short term exposure to di-n-butyl phthalate (DBP) disrupts ovarian function in young CD-1 mice. Reprod Toxicol. 2015;53:15-22

39. Li N, Liu T, Zhou L, He J, Ye L. Di-(2-ethylhcxyl) phthalate reduces progesterone levels and induces apoptosis of ovarian granulosa cell in adult female ICR mice. Environ Toxicol Pharmacol. 2012;34:869-75.

40. Hannon PR, Peretz J, Flaws JA. Daily exposure to Di(2-ethylhexyl) phthalate alters estrous cyclicity and accelerates primordial follicle recruitment potentially via dysregulation of the phosphatidylinositol 3-kinase signaling pathway in adult mice. Biol Reprod. 2014;90:136

41. Xu C, Chen JA, Qiu Z, Zhao Q, Luo J, Yang L, et al. Ovotoxicity and PPARmediated aromatase downregulation in female Sprague-Dawley rats following combined oral exposure to benzo[a]pyrene and di-(2-ethylhexyl) phthalate. Toxicol Lett. 2010;199:323-32.

42. Messerlian C, Souter I, Gaskins AJ, Williams PL, Ford JB, Chiu YH, et al. Urinary phthalate metabolites and ovarian reserve among women seeking infertility care. Hum Reprod. 2016;31:75-83.

43. Calafat AM, Kuklenyik Z, Reidy JA, Caudill SP, Ekong J, Needham LL. Urinary concentrations of bisphenol $A$ and 4-nonylphenol in a human reference population. Environ Health Perspect. 2005;113:391-5.

44. Berger A, Ziv-Gal A, Cudiamat J, Wang W, Zhou C, Flaws JA. The effects of in utero bisphenol $\mathrm{A}$ exposure on the ovaries in multiple generations of mice. Reprod Toxicol. 2016;60:39-52.

45. Zhang $\mathrm{HQ}$, Zhang XF, Zhang $\mathrm{L}$, Chao $\mathrm{HH}$, Pan B, Feng YM, et al. Fetal exposure to bisphenol $A$ affects the primordial follicle formation by inhibiting the meiotic progression of oocytes. Mol Biol Rep. 2012;39:5651-7.

46. Rodriguez HA, Santambrosio N, Santamaria CG, Munoz-de-Toro M, Luque $\mathrm{EH}$. Neonatal exposure to bisphenol A reduces the pool of primordial follicles in the rat ovary. Reprod Toxicol. 2010;30:550-7.
47. Li Y, Zhang W, Liu J, Wang W, Li H, Zhu J, et al. Prepubertal bisphenol A exposure interferes with ovarian follicle development and its relevant gene expression. Reprod Toxicol. 2014;44:33-40.

48. Souter I, Smith KW, Dimitriadis I, Ehrlich S, Williams PL, Calafat AM, et al. The association of bisphenol-A urinary concentrations with antral follicle counts and other measures of ovarian reserve in women undergoing infertility treatments. Reprod Toxicol. 2013;42:224-31.

49. Caserta D, Di Segni N, Mallozzi M, Giovanale V, Mantovani A, Marci R, et al. Bisphenol $A$ and the female reproductive tract: an overview of recent laboratory evidence and epidemiological studies. Reprod Biol Endocrinol. 2014:12:37.

50. Machtinger R, Orvieto R. Bisphenol A, oocyte maturation, implantation, and IVF outcome: review of animal and human data. Reprod Biomed Online. 2014:29:404-10

51. Kotil T, Yon ND. The effects of permethrin on rat ovarian tissue morphology. Exp Toxicol Pathol. 2015;67:279-85.

52. Satar DA, Tap O, Ay MO. Electron microscopic examination of the effects of methyl parathion exposure on the ovaries. Eur Rev Med Pharmacol Sci. 2015;19:2725-31.

53. Park S, Kim S, Jin H, Lee K, Bae J. Impaired development of female mouse offspring maternally exposed to simazine. Environ Toxicol Pharmacol. 2014; 38:845-51.

54. El-Sharkawy EE, Kames AO, Sayed SM, Nisr NA, Wahba NM, Elsherif WM, et al. The ameliorative effect of propolis against methoxychlor induced ovarian toxicity in rat. Exp Toxicol Pathol. 2014;66:415-21.

55. Bhattacharya $P$, Keating AF. Impact of environmental exposures on ovarian function and role of xenobiotic metabolism during ovotoxicity. Toxicol Appl Pharmacol. 2012;261:227-35.

56. Craig ZR, Hannon PR, Flaws JA. Pregnenolone co-treatment partially restores steroidogenesis, but does not prevent growth inhibition and increased atresia in mouse ovarian antral follicles treated with mono-hydroxy methoxychlor. Toxicol Appl Pharmacol. 2013;272:780-6.

57. Zama AM, Uzumcu M. Fetal and neonatal exposure to the endocrine disruptor methoxychlor causes epigenetic alterations in adult ovarian genes. Endocrinology. 2009;150:4681-91.

58. Farr SL, Cai J, Savitz DA, Sandler DP, Hoppin JA, Cooper GS. Pesticide exposure and timing of menopause: the Agricultural Health Study. Am J Epidemiol. 2006;163:731-42.

59. Baligar PN, Kaliwal BB. Induction of gonadal toxicity to female rats after chronic exposure to mancozeb. Ind Health. 2001;39:235-43.

60. Cooper GS, Savitz DA, Millikan R, Chiu Kit T. Organochlorine exposure and age at natural menopause. Epidemiology. 2002;13:729-33.

61. Akkina J, Reif J, Keefe T, Bachand A. Age at natural menopause and exposure to organochlorine pesticides in Hispanic women. J Toxicol Environ Health A. 2004;67:1407-22

62. Camlin NJ, McLaughlin EA, Holt JE. Through the smoke: use of in vivo and in vitro cigarette smoking models to elucidate its effect on female fertility. Toxicol Appl Pharmacol. 2014;281:266-75.

63. Matikainen T, Perez Gl, Jurisicova A, Pru JK, Schlezinger JJ, Ryu HY, et al. Aromatic hydrocarbon receptor-driven Bax gene expression is required for premature ovarian failure caused by biohazardous environmental chemicals. Nat Genet. 2001;28:355-60.

64. Anderson RA, Mcllwain L, Coutts S, Kinnell HL, Fowler PA, Childs AJ. Activation of the aryl hydrocarbon receptor by a component of cigarette smoke reduces germ cell proliferation in the human fetal ovary. Mol Hum Reprod. 2014;20:42-8.

65. Sobinoff AP, Beckett EL, Jarnicki AG, Sutherland JM, McCluskey A, Hansbro PM, et al. Scrambled and fried: cigarette smoke exposure causes antral follicle destruction and oocyte dysfunction through oxidative stress. Toxicol Appl Pharmacol. 2013;271:156-67.

66. Sun L, Tan L, Yang F, Luo Y, Li X, Deng HW, et al. Meta-analysis suggests that smoking is associated with an increased risk of early natural menopause. Menopause. 2012;19:126-32.

67. Harlow BL, Signorello LB. Factors associated with early menopause. Maturitas. 2000;35:3-9.

68. Parente RC, Faerstein E, Celeste RK, Werneck GL. The relationship between smoking and age at the menopause: a systematic review. Maturitas. 2008; 61:287-98.

69. Yasui T, Hayashi K, Mizunuma H, Kubota T, Aso T, Matsumura Y, et al. Factors associated with premature ovarian failure, early menopause and earlier onset of menopause in Japanese women. Maturitas. 2012;72:249-55. 
70. Fleming LE, Levis S, LeBlanc WG, Dietz NA, Arheart KL, Wilkinson JD, et al. Earlier age at menopause, work, and tobacco smoke exposure. Menopause. 2008;15:1103-8.

71. Tawfik H, Kline J, Jacobson J, Tehranifar P, Protacio A, Flom JD, et al. Life course exposure to smoke and early menopause and menopausal transition. Menopause. 2015;22:1076-83.

72. Chang SH, Kim CS, Lee KS, Kim H, Yim SV, Lim YJ, et al. Premenopausal factors influencing premature ovarian failure and early menopause. Maturitas. 2007;58:19-30

73. Peck JD, Quaas AM, Craig LB, Soules MR, Klein NA, Hansen KR. Lifestyle factors associated with histologically derived human ovarian non-growing follicle count in reproductive age women. Hum Reprod. 2016;31:150-7.

74. Progetto Menopausa Italia Study Group. Premature ovarian failure: frequency and risk factors among women attending a network of menopause clinics in Italy. BJOG. 2003;110:59-63.

75. Gregoraszczuk EL, Ptak A. Endocrine-disrupting chemicals: some actions of POPs on female reproduction. Int J Endocrinol. 2013;2013:828532.

76. Kilic S, Yuksel B, Lortlar N, Sertyel S, Aksu T, Batioglu S. Environmental tobacco smoke exposure during intrauterine period promotes granulosa cell apoptosis: a prospective, randomized study. J Matern Fetal Neonatal Med. 2012;25:1904-8.

77. Gannon AM, Stampfli MR, Foster WG. Cigarette smoke exposure leads to follicle loss via an alternative ovarian cell death pathway in a mouse model. Toxicol Sci. 2012;125:274-84.

78. Jurisicova A, Taniuchi A, Li H, Shang Y, Antenos M, Detmar J, et al. Maternal exposure to polycyclic aromatic hydrocarbons diminishes murine ovarian reserve via induction of Harakiri. J Clin Invest. 2007;117:3971-8.

79. Paixao LL, Gaspar-Reis RP, Gonzalez GP, Santos AS, Santana AC, Santos RM, et al. Cigarette smoke impairs granulosa cell proliferation and oocyte growth after exposure cessation in young Swiss mice: an experimental study. J Ovarian Res. 2012;5:25.

80. Caserta D, Bordi G, Di Segni N, D’Ambrosio A, Mallozzi M, Moscarini M. The influence of cigarette smoking on a population of infertile men and women. Arch Gynecol Obstet. 2013;287:813-8.

81. Freour T, Masson D, Mirallie $S$, Jean M, Bach K, Dejoie T, et al. Active smoking compromises IVF outcome and affects ovarian reserve. Reprod Biomed Online. 2008;16:96-102.

82. Camlin NJ, Sobinoff AP, Sutherland JM, Beckett EL, Jarnicki AG, Vanders RL, et al. Maternal smoke exposure impairs the long-term fertility of female offspring in a murine model. Biol Reprod. 2016;94:39.

83. Fraser A, McNally W, Sattar N, Anderson EL, Lashen H, Fleming R, et al. Prenatal exposures and anti-Mullerian hormone in female adolescents: the Avon Longitudinal Study of Parents and Children. Am J Epidemiol. 2013;178:1414-23.

84. Strohsnitter WC, Hatch EE, Hyer M, Troisi R, Kaufman RH, Robboy SJ, et al. The association between in utero cigarette smoke exposure and age at menopause. Am J Epidemiol. 2008;167:727-33.

85. Fowler PA, Childs AJ, Courant F, MacKenzie A, Rhind SM, Antignac JP, et al In utero exposure to cigarette smoke dysregulates human fetal ovarian developmental signalling. Hum Reprod. 2014;29:1471-89.

86. Ernst A, Kristensen SL, Toft G, Thulstrup AM, Hakonsen LB, Olsen SF, et al. Maternal smoking during pregnancy and reproductive health of daughters: a follow-up study spanning two decades. Hum Reprod. 2012;27:3593-600.

87. Lutterodt MC, Sorensen KP, Larsen KB, Skouby SO, Andersen CY, Byskov AG. The number of oogonia and somatic cells in the human female embryo and fetus in relation to whether or not exposed to maternal cigarette smoking. Hum Reprod. 2009;24:2558-66.

88. Butts SF, Sammel MD, Greer C, Rebbeck TR, Boorman DW, Freeman EW. Cigarettes, genetic background, and menopausal timing: the presence of single nucleotide polymorphisms in cytochrome P450 genes is associated with increased risk of natural menopause in European-American smokers. Menopause. 2014;21:694-701.

89. Lim J, Lawson GW, Nakamura BN, Ortiz L, Hur JA, Kavanagh TJ, et al. Glutathione-deficient mice have increased sensitivity to transplacental benzo[a]pyrene-induced premature ovarian failure and ovarian tumorigenesis. Cancer Res. 2013;73:908-17.

90. Sirotkin AV, Harrath AH. Phytoestrogens and their effects. Eur J Pharmacol. 2014;741:230-6.

91. Wang W, Sun Y, Liu J, Li Y, Li H, Xiao S, et al. Soy isoflavones administered to rats from weaning until sexual maturity affect ovarian follicle development by inducing apoptosis. Food Chem Toxicol. 2014;72:51-60.
92. Jefferson WN, Padilla-Banks E, Newbold RR. Disruption of the female reproductive system by the phytoestrogen genistein. Reprod Toxicol. 2007;23:308-16.

93. Guillette Jr LJ, Moore BC. Environmental contaminants, fertility, and multioocytic follicles: a lesson from wildlife? Semin Reprod Med. 2006;24:134-41.

94. Kim SH, Park MJ. Effects of phytoestrogen on sexual development. Korean J Pediatr. 2012;55:265-71.

95. Patel S, Zhou C, Rattan S, Flaws JA. Effects of endocrine-disrupting chemicals on the ovary. Biol Reprod. 2015;93:20.

96. Hombach-Klonisch S, Pocar P, Kietz S, Klonisch T. Molecular actions of polyhalogenated arylhydrocarbons (PAHs) in female reproduction. Curr Med Chem. 2005;12:599-616.

97. Sharma R, Sharma M, Sharma R, Sharma V. The impact of incinerators on human health and environment. Rev Environ Health. 2013;28:67-72.

98. Sorg O. AhR signalling and dioxin toxicity. Toxicol Lett. 2014;230:225-33.

99. White SS, Birnbaum LS. An overview of the effects of dioxins and dioxin-like compounds on vertebrates, as documented in human and ecological epidemiology. J Environ Sci Health C Environ Carcinog Ecotoxicol Rev. 2009;27:197-211.

100. Shi Z, Valdez KE, Ting AY, Franczak A, Gum SL, Petroff BK. Ovarian endocrine disruption underlies premature reproductive senescence following environmentally relevant chronic exposure to the aryl hydrocarbon receptor agonist 2,3,7,8-tetrachlorodibenzo-p-dioxin. Biol Reprod. 2007;76:198-202.

101. Eskenazi B, Warner M, Marks AR, Samuels S, Gerthoux PM, Vercellini $P$, et al. Serum dioxin concentrations and age at menopause. Environ Health Perspect. 2005;113:858-62.

102. Vorkamp K. An overlooked environmental issue? A review of the inadvertent formation of PCB-11 and other PCB congeners and their occurrence in consumer products and in the environment. Sci Total Environ. 2016;541:1463-76

103. Pocar P, Brevini TA, Fischer B, Gandolfi F. The impact of endocrine disruptors on oocyte competence. Reproduction. 2003;125:313-25.

104. Shirota M, Mukai M, Sakurada Y, Doyama A, Inoue K, Haishima A, et al. Effects of vertically transferred 3,3,4,4',5-pentachlorobiphenyl (PCB-126) on the reproductive development of female rats. J Reprod Dev. 2006;52:751-61.

105. Pocar P, Fiandanese N, Secchi C, Berrini A, Fischer B, Schmidt JS, et al. Effects of polychlorinated biphenyls in CD-1 mice: reproductive toxicity and intergenerational transmission. Toxicol Sci. 2012;126:213-26.

106. Grandjean P, Clapp R. Perfluorinated Alkyl Substances: Emerging Insights Into Health Risks. New Solut. 2015;25:147-63.

107. Taylor KW, Hoffman K, Thayer KA, Daniels JL. Polyfluoroalkyl chemicals and menopause among women 20-65 years of age (NHANES). Environ Health Perspect. 2014;122:145-50.

108. Knox SS, Jackson T, Javins B, Frisbee SJ, Shankar A, Ducatman AM. Implications of early menopause in women exposed to perfluorocarbons. J Clin Endocrinol Metab. 2011;96:1747-53.

109. Boekelheide K, Darney SP, Daston GP, David RM, Luderer U, Olshan AF, et al. NTP-CERHR Expert Panel Report on the reproductive and developmental toxicity of 2-bromopropane. Reprod Toxicol. 2004;18:189-217.

110. Kinney A, Kline J, Kelly A, Reuss ML, Levin B. Smoking, alcohol and caffeine in relation to ovarian age during the reproductive years. Hum Reprod. 2007;22:1175-85.

111. Lefevre PL, Berger RG, Ernest SR, Gaertner DW, Rawn DF, Wade MG, et al. Exposure of female rats to an environmentally relevant mixture of brominated flame retardants targets the ovary,affecting folliculogenesis and steroidogenesis. Biol Reprod. 2016;94:9.

112. Ogliari KS, Lichtenfels AJ, de Marchi MR, Ferreira AT, Dolhnikoff M, Saldiva PH. Intrauterine exposure to diesel exhaust diminishes adult ovarian reserve. Fertil Steril. 2013;99:1681-8.

113. Nakamura N, Inselman AL, White GA, Chang CW, Trbojevich RA, Sephr E, et al. Effects of maternal and lactational exposure to 2-hydroxy-4-methoxybenzone on development and reproductive organs in male and female rat offspring. Birth Defects Res B Dev Reprod Toxicol. 2015;104:35-51.

114. Pelosi E, Simonsick E, Forabosco A, Garcia-Ortiz JE, Schlessinger D. Dynamics of the ovarian reserve and impact of genetic and epidemiological factors on age of menopause. Biol Reprod. 2015:92:130.

115. Gore AC, Chappell VA, Fenton SE, Flaws JA, Nadal A, Prins GS, et al. EDC-2: the endocrine Society's second scientific statement on endocrinedisrupting chemicals. Endocr Rev. 2015;36:E1-150. 
116. Zheng W, Nagaraju G, Liu Z, Liu K. Functional roles of the phosphatidylinositol 3-kinases (PI3Ks) signaling in the mammalian ovary. Mol Cell Endocrinol. 2012;356:24-30.

117. Siroux V, Agier L, Slama R. The exposome concept: a challenge and a potential driver for environmental health research. Eur Respir Rev. 2016;25:124-9.

118. Rappaport SM. Genetic factors are not the major causes of chronic diseases. PLoS One. 2016;11:e0154387.

Submit your next manuscript to BioMed Central and we will help you at every step:

- We accept pre-submission inquiries

- Our selector tool helps you to find the most relevant journal

- We provide round the clock customer support

- Convenient online submission

- Thorough peer review

- Inclusion in PubMed and all major indexing services

- Maximum visibility for your research

Submit your manuscript at www.biomedcentral.com/submit 